Research Paper

\title{
Chronometry and formation pathways of gypsum using Electron Spin Resonance and Fourier Transform Infrared Spectroscopy
}

\author{
Y.C. Nagar ${ }^{\text {a,1 }}$, M.D. Sastry ${ }^{\text {a }}$, B. Bhushan ${ }^{b}$, A. Kumar ${ }^{c}$, K.P. Mishra ${ }^{c}$, A. Shastri ${ }^{d}$, M.N. Deo ${ }^{\text {e }}$, G. Kocurek ${ }^{f}$, \\ J.W. Magee $^{\text {g, S.K. } \text { Wadhawan }^{\text {h }} \text {, N. Juyal }}{ }^{\text {a }}$, M.S. Pandian ${ }^{\text {i }}$, A.D. Shukla ${ }^{\text {a }, ~ A . K . ~ S i n g h v i ~}{ }^{\text {a, }}$ \\ a Physical Research Laboratory, Navrangpura, Ahmedabad 380 009, India \\ ${ }^{\mathrm{b}}$ Food Technology Division, Bhabha Atomic Research Center, Mumbai 400 085, India \\ ${ }^{c}$ Radiation Biology \&' Health Sciences Division, Bhabha Atomic Research Center, Mumbai 400 085, India \\ ${ }^{\mathrm{d}}$ Atomic and Molecular Physics Division, Bhabha Atomic Research Centre, Mumbai 400 085, India \\ ${ }^{\mathrm{e}}$ High Pressure and Synchroton Radiation Physics, Bhabha Atomic Research Centre, Mumbai 400 085, India \\ ${ }^{\mathrm{f}}$ Department of Geosciences, Texas University, Austin, TX 78712, USA \\ ${ }^{\mathrm{g}}$ Research School of Earth Sciences, The Australian National University, Canberra, A. C. T. 0200, Australia \\ ${ }^{\mathrm{h}}$ Geological Survey of India, Sector 10, Gandhinagar, Gujarat, India \\ ${ }^{\mathrm{i}}$ Earth Science Department, Pondicherry University, India
}

\section{A R T I C L E I N F O}

\section{Article history:}

Received 6 January 2010

Received in revised form 4 May 2010

Accepted 7 May 2010

Available online 13 May 2010

\section{Keywords:}

Gypsum

Hannebachite

ESR

FT-IR

Thar Desert

White sands

\begin{abstract}
A B S T R A C T
Gypsum is an authigenic precipitate that forms under periods of accentuated aridity and occurs widely in arid zones. However its use in quantitative paleoclimatology has been limited due to the absence of a method to determine the timing of its formation. We present here the results of a feasibility study that demonstrates that the timing of the formation event of gypsum can be estimated using Electron Spin Resonance (ESR) analysis. We used well documented samples from White Sands in New Mexico, USA, the Thar Desert, India and lakes in the Simpson Desert and Mallee Region, Australia and found that ESR ages could be obtained using radiation sensitive $\mathrm{SO}_{4}, \mathrm{SO}_{3}^{-}$radicals and a photobleachable signal $\mathrm{O}_{3}$. ESR signals were consistent with control ages based on contextual information. These suggest that the dating signals $\left(\mathrm{SO}_{4}^{-}, \mathrm{SO}_{3}^{-}\right)$are stable over time scales $>100 \mathrm{ka}$. We propose that this stability of the $\mathrm{SO}_{4}^{-}$signals over geological time scales arises due to hydrogen bonding between the water proton and the $\mathrm{SO}_{4}^{-}$ radical and that the suitability of these radiation-induced radicals comes from their being a part of the host matrix. Further, ESR along with Fourier Transform Infrared (FT-IR) Spectroscopy methods additionally inform on the geochemical pathways for gypsum formation and help elucidate complex formation processes even in samples that appeared unambiguous gypsum precipitates. Thus, the presence of Hannebachite $\left(\mathrm{CaSO}_{3} \cdot \frac{1}{2} \mathrm{H}_{2} \mathrm{O}\right)$ and $\mathrm{Mn}^{2+}$ in Thar and Australian samples suggested a reducing environment such that low valence sulfur reacted with $\mathrm{CaCO}_{3}$ to form hannebachite and eventually gypsum. The presence of sulfur, partially as sulfite in Thar gypsum samples suggested that redox cycles were mediated by microbial activity. Absence of these features in White Sands samples suggested oxic conditions during gypsum precipitation.
\end{abstract}

(c) 2010 Elsevier B.V. All rights reserved.

\section{Introduction}

Gypsum, $\mathrm{CaSO}_{4} \cdot 2 \mathrm{H}_{2} \mathrm{O}$ is an evaporite that forms as the final precipitate from brines, under periods of accentuated aridity. It thus informs on the paleohydrology and past environments in lacustrine and marine settings (e.g. Chivas, 2008; Davies, 2005; Ikeya et al., 1997; Pajon et al., 2001; Torfstein et al., 2008). In

\footnotetext{
* Corresponding author. Tel.: +91 79 26314366; fax: +91 7926301502. E-mail address: singhvi@prl.res.in (A.K. Singhvi).

1 Present address: Snow and Avalanche Study Establishment, Manali, India.
}

nature, gypsum generally forms through two pathways. The first one is by a direct precipitation of $\mathrm{CaSO}_{4}$ and the second is the precipitation through sulfur produced by microbial activity in the form of dimethyl-sulfonio propionate (Seal et al., 2000). Microbial activity plays an important mediatory role in reducing sulfur (VI), as in $\mathrm{SO}_{4}^{2-}$, to $\mathrm{H}_{2} \mathrm{~S}$ and/or metal sulfides such as pyrite $\left(\mathrm{FeS}_{2}\right)$. Under favorable conditions, sulfur gets oxidized to $\mathrm{SO}_{2} / \mathrm{SO}_{4}$, which reacts with $\mathrm{CaCO}_{3}$ to form gypsum. In saline lakes, the salinity controls the reaction between $\mathrm{CaCO}_{3}$ and sulfate to form $\mathrm{CaSO}_{4} \cdot 2 \mathrm{H}_{2} \mathrm{O}$. The final product retains some of the 'markers' of intermediate steps that help elucidate the processes responsible for gypsum formation. In gypsum precipitated from saline water, the typical carbonate 
concentration is $3-8 \%$, and this concentration is higher in cases where sulfur is produced through microbial activity. Further, gypsum formation triggered by a chemical pathway and with low valent sulfoxides as reaction intermediates should be associated with significant amount of hannebachite (Hentschel et al., 1985; Laperche and Bigham, 2002).

Electron Spin Resonance (ESR) of radiation-induced paramagnetic defects has been a geochronology tool for a variety of samples (Marfunin, 1979; Grun, 1991; Ikeya, 1993; Ulusoy, 2004). Radiation-induced centers in inorganic sulfates, carbonates, silicates, phosphates etc. have been investigated. Radical ions such as $\mathrm{SO}_{4}^{-}, \mathrm{SO}_{3}^{-}, \mathrm{CO}_{2}^{-}$etc. and their radiation dependent yields can be related to the major constituents in gypsum.

The present study used ESR and FT-IR analysis of gypsum samples from White Sands USA (WS), Thar Desert, India (TD) and from Australia (AS). The results revealed that WS and AS samples were fully formed "pure" gypsum. In contrast, the TD samples were either as gypsum crystals or as powdery gypsum that occurred along with hannebachite and calcite. These serve as examples of "beginnings of gypsum formation" in weakly oxidizing conditions of playas in Thar region. From the point of ESR-chronometry, TD samples offered both challenges (and hence more opportunities) compared to fully formed WS gypsum. The dating signal in the WS samples and other crystalline gypsum was $\mathrm{SO}_{4}^{-}$and the $\mathrm{SO}_{3}^{-}$was used for samples with hannebachite. Further, a new light sensitive ESR center in gypsum was detected, that can provide additional chronometric inputs on the daylight exposure after gypsum formation and enable dating of the transport of gypsum crystals from dunes.

In the following, the current status of ESR dating of gypsum is reviewed so as to place the present work in a proper context.

\subsection{ESR dating of gypsum}

ESR dating of gypsum comprises a quantitative measurement of the concentration of radiation-induced paramagnetic centers. In nature, the decay of naturally occurring $U$, Th and $K$ along with the cosmic rays provide the radiation field. This radiation field induces paramagnetic centers in the sample in a cumulative manner. Using appropriate laboratory calibration experiments, the ESR intensity of the sample as received is converted into radiation dose units. This is termed as the paleodose $\left(D_{e}\right)$. Elemental concentrations of natural radioactivity and their daughter enable computation of the annual dose and the ratio of paleodose with dose rate provides the age, (Grun, 1991). In the present case, the event dated is the precipitation event of gypsum or a later date transport event (if a photo (daylight)-bleachable signal is used).

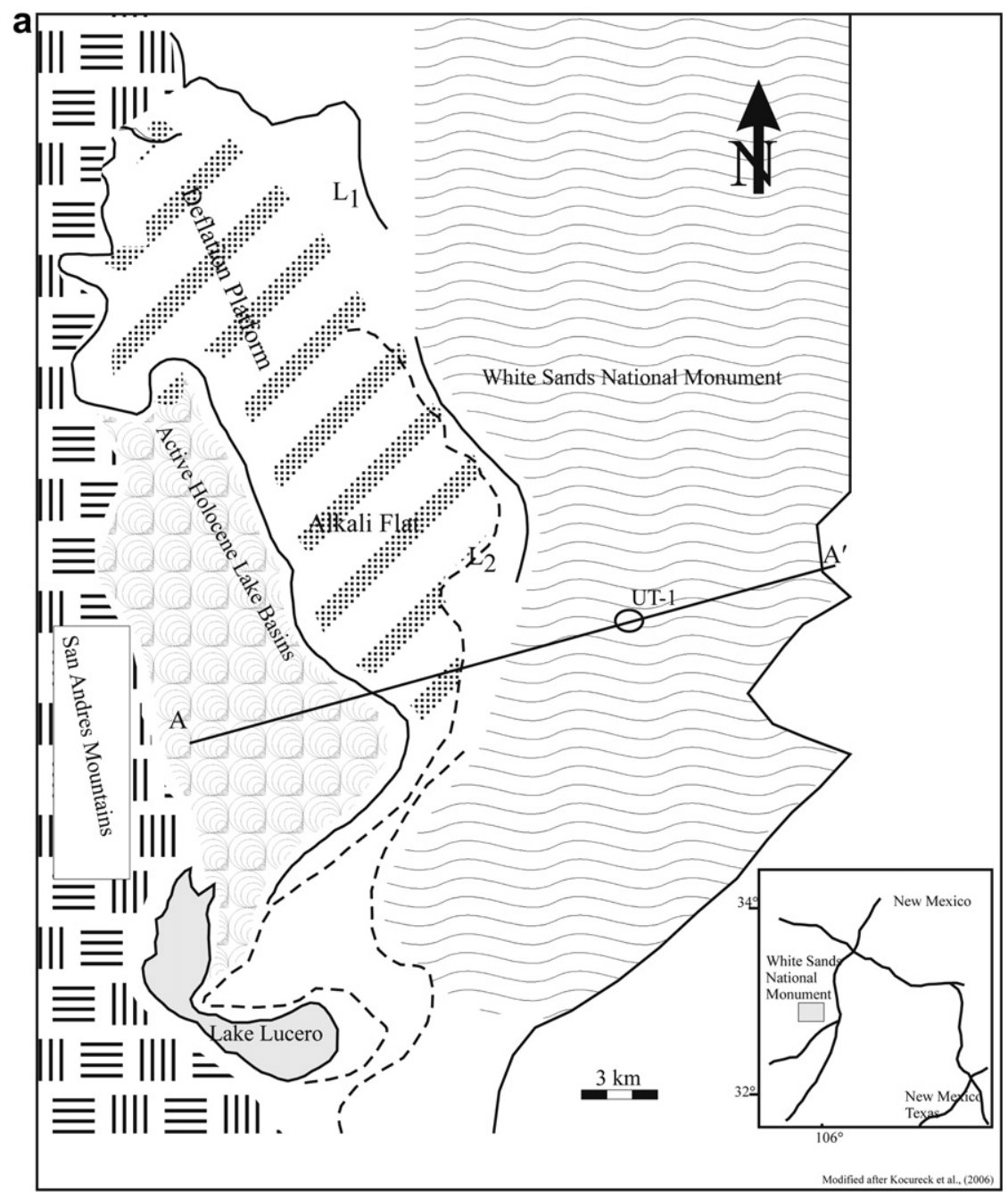

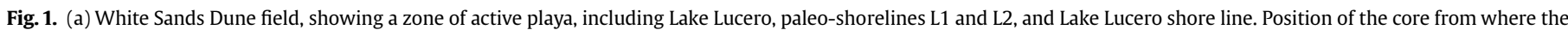

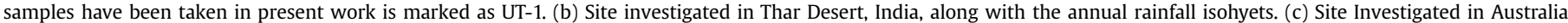
(Simpson Desert and Malee Region). 

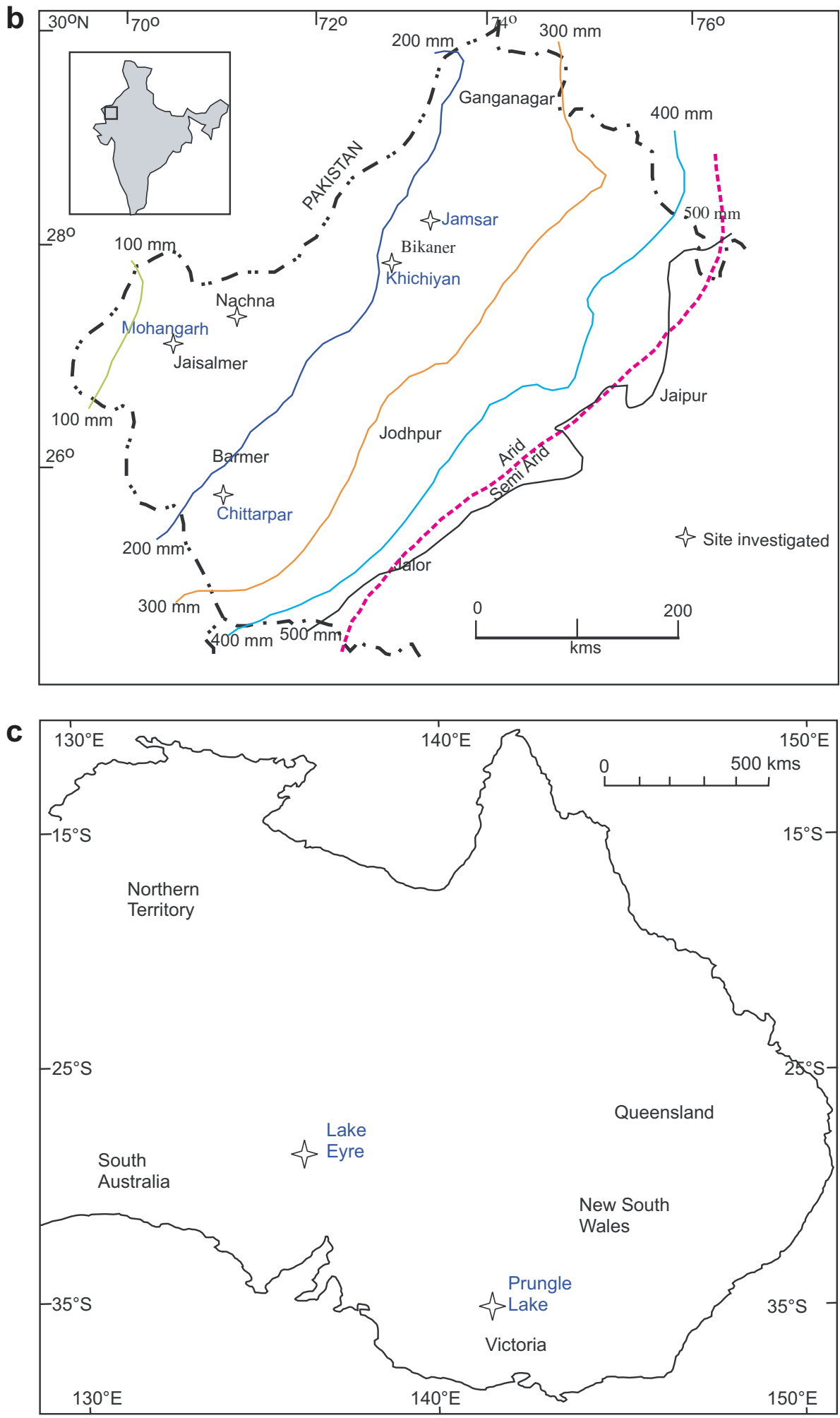

Fig. 1. (continued). 
Nambi (1982) attempted on ESR dating of marine gypsum using signals at $g=2.0040$ and estimated the paleodose that ranged from 66 Gy to 74 Gy. Yijian et al. (1989) concluded that in gypsum ESR, the only signal suitable for dating is at $g=2.008$. Kasuya et al. (1991) investigated the radiation-induced paramagnetic centers in a gypsum single crystal and identified four signals $G_{1}-G_{4}$. The first signal (termed $\mathrm{G}_{1}$ ) at $g=2.0003$ was isotropic and using the hyperfine structure of ${ }^{33} \mathrm{~S}$, Kasuya et al. (1991) identified this as $\mathrm{SO}_{3}^{-}$ species which is a trapped electron center at an oxygen vacancy. The second center $\mathrm{G}_{2}$ had $g_{\mathrm{xx}}=2.0084, g_{\mathrm{yy}}=2.0088$ and $g_{\mathrm{zz}}=2.0192$. The species responsible for this center were not identified; however a suggestion on its being an electron deficient center was made. Center $\mathrm{G}_{3}$ had $g_{\mathrm{xx}}=2.0029$ (parallel to c-axis), $g_{\mathrm{yy}}=2.0027$ (parallel to b-axis) and $g_{z z}=1.9973$ (parallel to a-axis). The center $G_{4}$, had a doublet hyperfine structure and was identified as being due to $\mathrm{O}_{2} \mathrm{H}$.

Ikeda and Ikeya (1992) investigated the ESR signal in natural and synthetic gypsum samples and found that the intensity of $\mathrm{G}_{2}$ center $\left(g_{\|}=2.0196, g_{\perp}=2.008\right)$ increased in carbonate doped samples, and hence attributed the $\mathrm{G}_{2}$ center to a $\mathrm{CO}_{3}^{-}$radical. Using this center for ESR dating, they estimated an age of 260-300 years for a tectonic event associated with the San Andreas Fault. The components of $g$ tensor of $\mathrm{CO}_{3}^{-}$do not coincide with those of $\mathrm{G}_{2}$, (only the $g_{\text {iso }}$ values are same) and are in fact nearer to those reported for $\mathrm{SO}_{4}^{-}$. It is therefore possible that increased intensity of $\mathrm{G}_{2}$ in carbonate doped samples, reported by Ikeda and Ikeya (1992) were artifacts of the presence of interstitial anion radicals in carbonate doped samples which increased the yield of $\mathrm{SO}_{4}^{-}$for charge compensation. The signal $\mathrm{G}_{2}$ was also used by Mathew et al. (2004) to date gypsum in faults. A key element missing in these studies was a discussion on stability of the signals and a comparison with secured age controls. We present here new results on the centers, discuss their stability aspects and demonstrate that gypsum can be used for a direct dating.

\section{Samples and methods}

Natural gypsum samples from, 1) White Sands (Gypsum sand) area, New Mexico, $\left(32^{\circ} 40^{\prime} \mathrm{N}, 106^{\circ} 10^{\prime} \mathrm{W}\right)$ USA, 2) Playa-lakes in Thar Desert at Jamsar $\left(28.01^{\circ} \mathrm{N}, 73.22^{\circ} \mathrm{E}\right)$, Mohangarh $\left(27.17^{\circ} \mathrm{N} 71.18^{\circ} \mathrm{E}\right)$, Khichiyan $\left(28^{\circ} 13^{\prime} \mathrm{N}, 73^{\circ} 20^{\prime} \mathrm{E}\right)$, Chhitarpar $\left(25.45^{\circ} \mathrm{N}, 71.25^{\circ} \mathrm{E}\right)$ and Nachna $\left(26.55^{\circ} \mathrm{N}, 70.57^{\circ} \mathrm{E}\right)$, India, and 3$)$ Lakes Punkrakadarinna and Prungle in Australia (Fig. 1a-c) were investigated. The samples were chosen for their varied geographic locations and, due to the existence of independent numerical age controls for these samples. The WS

Table 1

Parameters used for ESR study.

\begin{tabular}{lll}
\hline Parameters & Sample & \\
\cline { 2 - 3 } & Thar & White Sands and Australia \\
\hline Field & & \\
$\quad$ Central field & 3470.000 & 3465.000 \\
Sweep width & 24.000 & 50.000 \\
Resolution & 1024 & 1024 \\
Microwave & & \\
Frequency & $9.717 \mathrm{GHz}$ & $9.717 \mathrm{GHz}$ \\
Power & $0.799 \mathrm{mw}$ & $5.029 \mathrm{mw}$ \\
Receiver & & \\
Receiver gain & $54 \mathrm{~dB}$ & $54 \mathrm{~dB}$ \\
Phase & $0.00 \mathrm{deg}$. & $0.00 \mathrm{deg}$. \\
Harmonic & 1 & 1 \\
Mod. freq. & $100.00 \mathrm{kHz}$ & $100.00 \mathrm{kHz}$ \\
Mod. amplitude & $1.00 \mathrm{G}$ & $1.00 \mathrm{G}$ \\
Signal channel & & $40.960 \mathrm{~ms}$ \\
Conversion & $40.960 \mathrm{~ms}$ & $327.680 \mathrm{~ms}$ \\
Time constant & $163.840 \mathrm{~ms}$ & $41.943 \mathrm{~s}$ \\
Sweep time & $41.643 \mathrm{~s}$ & \\
\hline
\end{tabular}

samples were from a $9 \mathrm{~m}$ core in the White Sands Dune Field. The sampling was done by coring in the Lake Lucero in the Tularosa Basin of the Rio Grande Rift in southern New Mexico. The lake sequences of Thar and Australia had gypsum layers alternating with sand/clay. The Thar and the White Sands samples were handled under subdued red light during collection and processing. Subsequent measurements, however, indicated that the principal centers were light insensitive and this permitted the use of the Australian samples from laboratory collections that had been exposed to daylight. The supporting field and geochronometric information of the Australian sample is available in Bowler (1998), Bowler and Price (1998) and Bowler et al. (2003).

\section{Experimental}

\subsection{Measurement details}

The purity of the samples was ascertained using Differential Thermal Analysis (DTA) and Thermogravimetry (TG) at the Analytical Chemistry Division, Bhabha Atomic Research Center
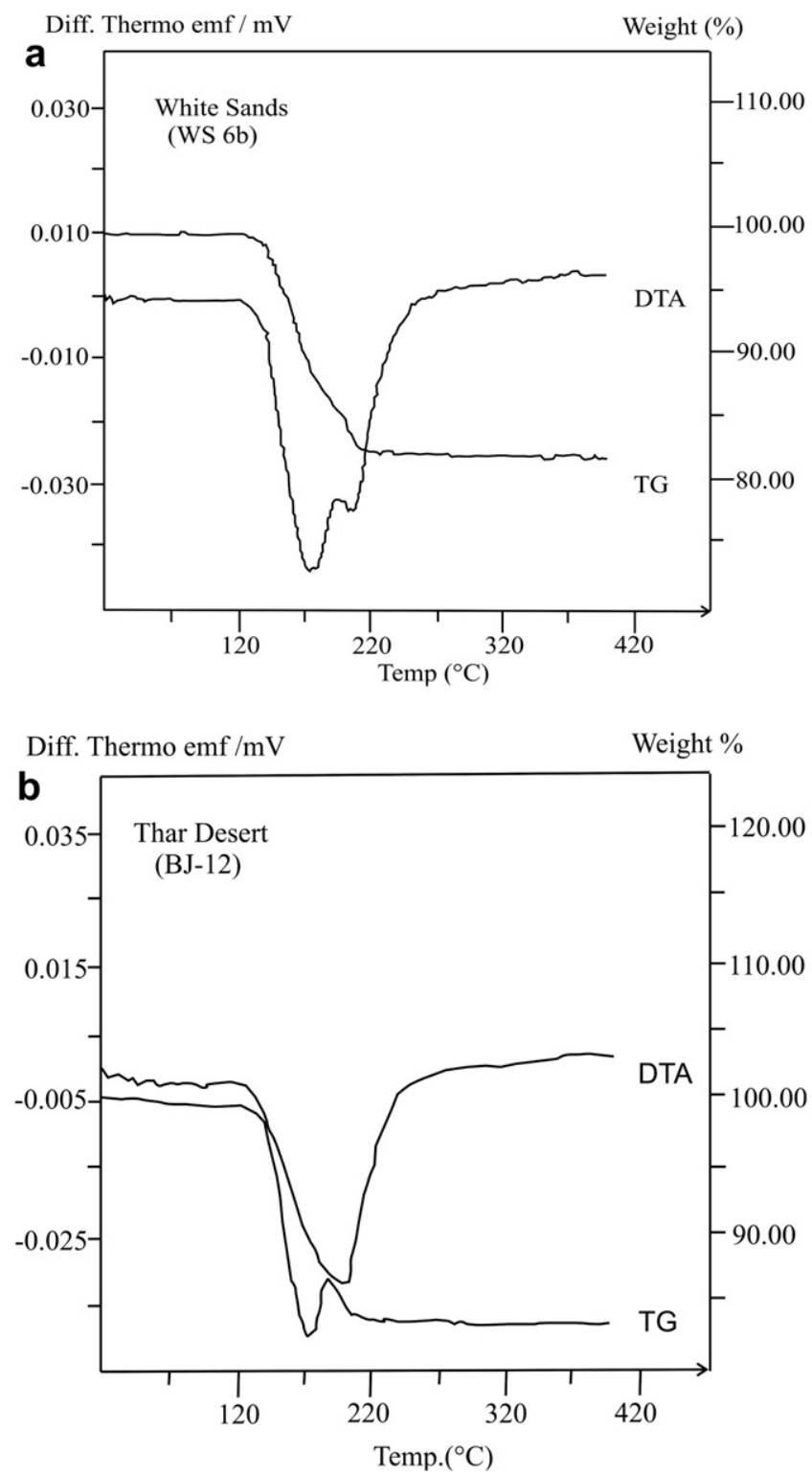

Fig. 2. Thermograms with simultaneous measurements of thermogravimetry (TG) and differential thermal analysis (DTA) of gypsum samples: (a) WS-6b (b) BJ-12. 
(BARC) Mumbai and powder X-Ray diffraction measurement on samples were ground to $<50 \mu \mathrm{m}$ size using X-ray diffractometer using a copper target. The data was collected from 5 to $80^{\circ}(2 \theta)$ using a scanning speed of $2^{\circ} / \mathrm{min}$.

The ESR measurements were made on samples as received and then were gamma irradiated to several doses in the range of $5 \mathrm{~Gy}-2.5 \mathrm{kGy}$ at $25^{\circ} \mathrm{C}$ in a ${ }^{60} \mathrm{Co}$ gamma cell, calibrated using a Fricke dosimeter. The dose rate to gypsum was $0.033 \mathrm{~Gy} / \mathrm{s}$. A Bruker Emx6/ $1 \mathrm{X}$-band spectrometer was used for ESR measurements at room temperature. Typically, for ESR measurements, 30-40 mg samples were loaded in Wilmad quartz tubes with $3.5 \mathrm{~mm}$ OD. The data collection and analysis were done using an on-line computer controlled data acquisition system. The spectra were analyzed using the WIN-EPR software. The parameters used for this study are shown in Table 1 . The $\mathrm{S} / \mathrm{N}$ ratio and $\mathrm{Q}$ of the loaded cavity for daylight-exposed samples were slightly higher, possibly due to partial evaporation of surface moisture. The intensity of such signals was normalized against the intensity of DPPH.
The FT-IR spectral data in the range $700-4500 \mathrm{~cm}^{-1}$, was obtained using a BOMEM DA8 FT-IR spectrometer in the evacuated mode. The spectrometer was equipped with a globar source, a $\mathrm{KBr}$ beam-splitter and liquid nitrogen cooled (77 K) HgCdTe (MCT) detector. The $\mathrm{KBr}$ pellet using samples mixed in concentrations of $1 \%$ and $0.5 \%$ by weight in $200 \mathrm{mg}$ of anhydrous $\mathrm{KBr}$ were used. A pellet of pure $\mathrm{KBr}$ served as the background reference for the absorbance. Spectra in transmission mode were converted to an absorbance versus wave number plot using standard software. Typical spectral resolution was $2 \mathrm{~cm}^{-1}$.

\subsection{Annual radiation dose: measurement and computation}

The annual dose was computed using concentration of $U$, Th and K using high-resolution gamma spectrometry (Olley et al., 1996; Ademic and Aitken, 1998). For WS, cosmic-ray dose was the dominant contributor and hence the average cosmic-ray dose rate (mean of the dose rate at the sample depth and that at the surface)
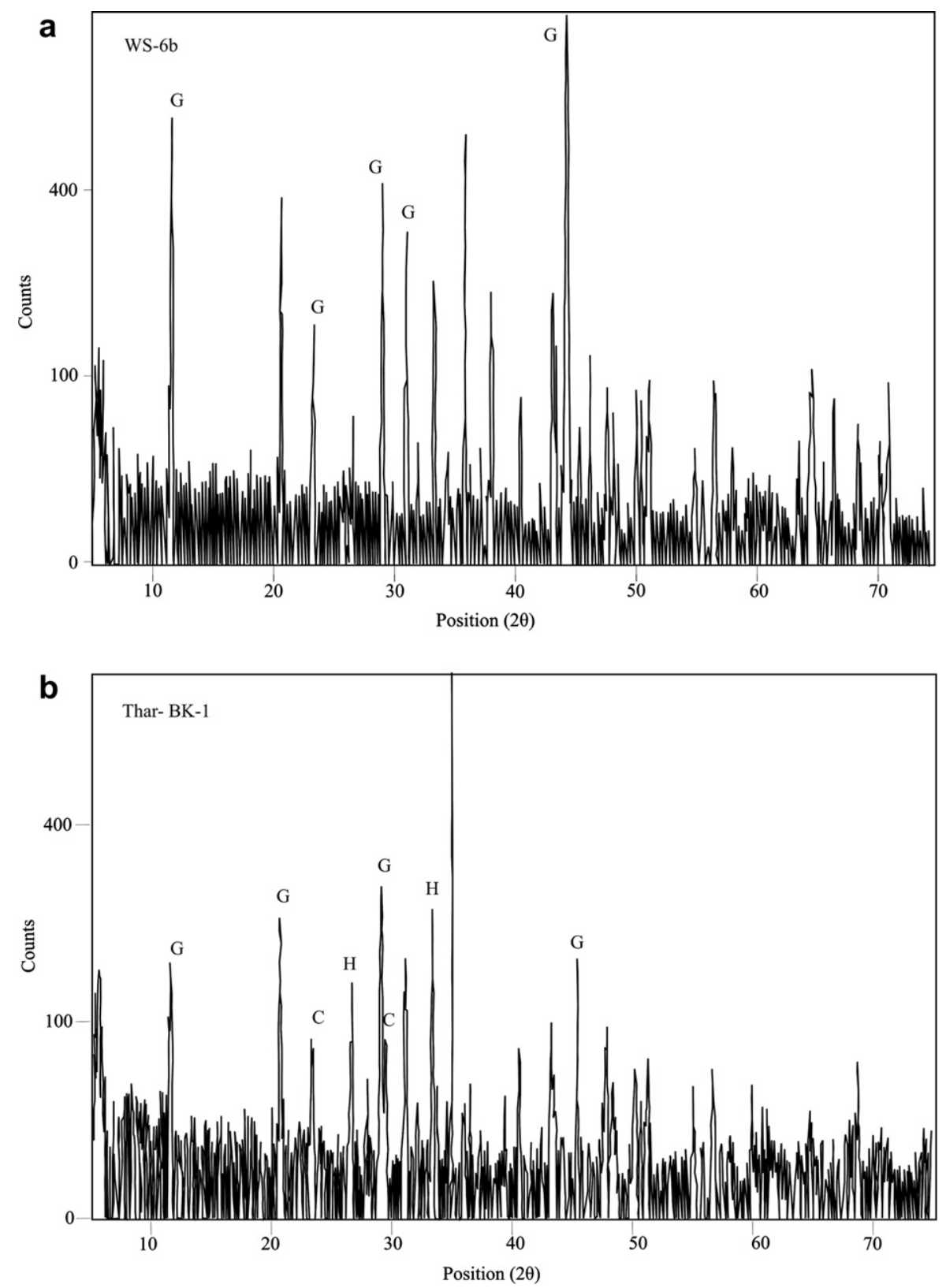

Fig. 3. X-ray diffraction pattern of gypsum samples (a) WS-6b, and (b) TD-BK-1. (G = Gypsum, C = Calcite and H = Hannebachite). 
was used. This approximation provided for changing irradiation geometry due to changing sediment overburden with time. Earlier studies did not consider the internal alpha dose, which contributes significantly as $U$ and $T h$ are dispersed in the volume of the gypsum grains. Thus annual dose, taking the alpha into account, with an alpha-efficiency factor $(a=0.25)$ measured for samples BK-1 and WS-6b using an alpha irradiation facility (Aitken and Bowman, 1975; Singhvi and Aitken, 1978), implied a 50\% change in previously reported ages. In the absence of any age controls, this lacuna remained undetected. In this, it is implicitly assumed that the OSL and ESR alpha efficiencies are similar. Theoretically, however the ESR efficiencies could be somewhat higher but the general concordance with other ages indicates that the alpha efficiencies used here are reasonable.

\section{Results}

\subsection{Sample characterization}

\subsubsection{TG/DTA}

Typical TG/DTA thermograms are shown in Fig. 2. These thermograms, as also of crystalline gypsum samples agree with the published reports on pure gypsum showing loss of water of hydration at $150{ }^{\circ} \mathrm{C}$ and $220{ }^{\circ} \mathrm{C}$. The DTA/TG of hannebachite $\left(\mathrm{CaSO}_{3} \cdot 1 / 2 \mathrm{H}_{2} \mathrm{O}\right.$ ), rich sample also had a similar pattern (Fig. $2 \mathrm{~b}$ ) albeit with reduced intensity reflecting lower fraction of gypsum. DTA/TG of hannebachite $\left(\mathrm{CaSO}_{3} \cdot 1 / 2 \mathrm{H}_{2} \mathrm{O}\right)$ is not available for comparison and the expected differential loss of weight of 1 in 137 cannot be easily detected.

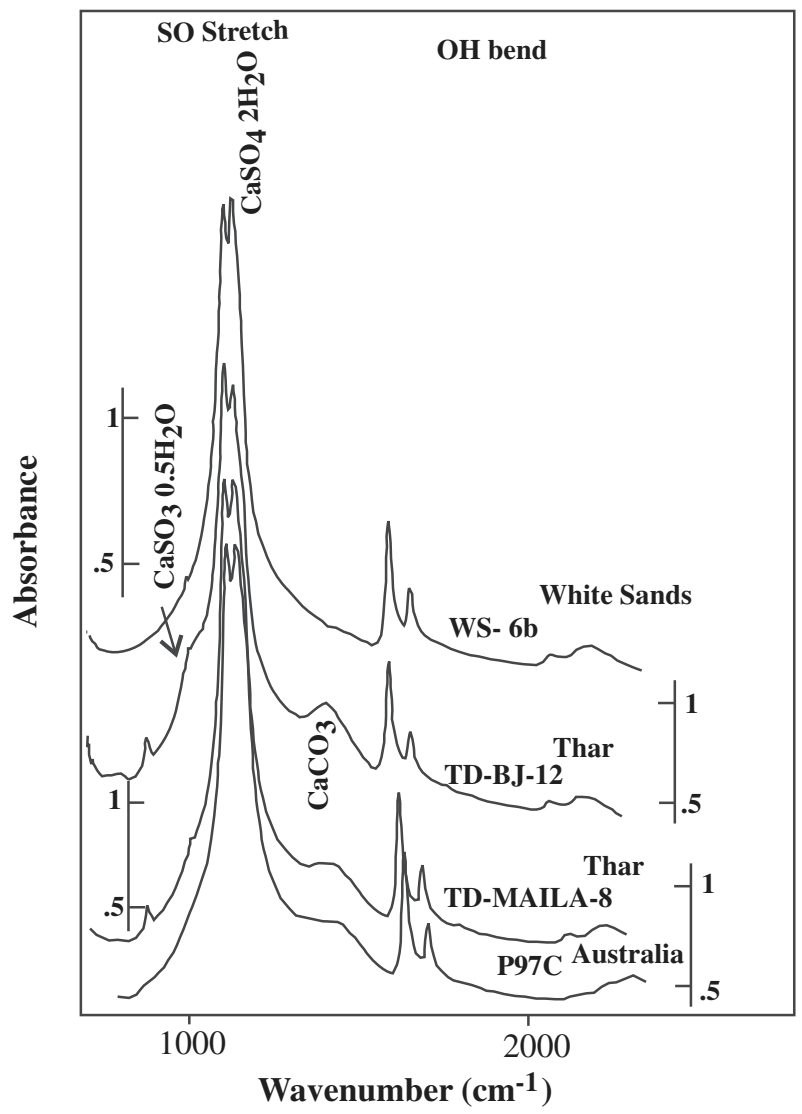

Fig. 4. Fourier Transform Infra-red (FT-IR) spectra of gypsum samples (6b, BJ-12 MILA-8, and $\mathrm{P} 97 \mathrm{C}$ ) in absorption mode.
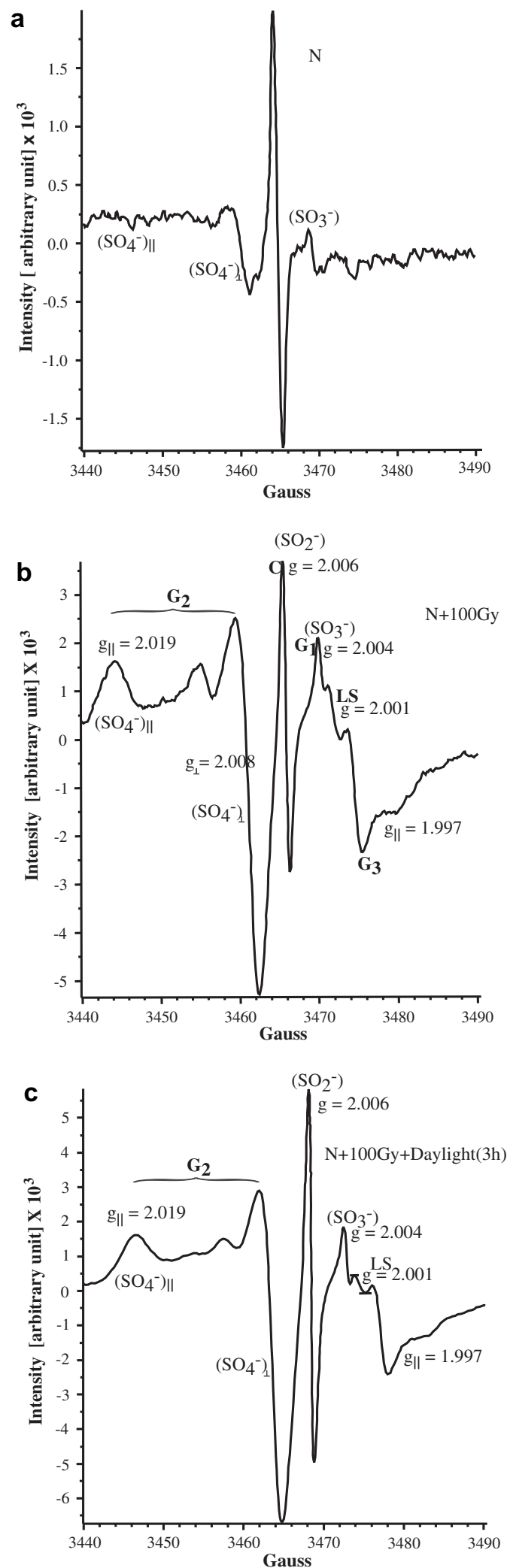

Fig. 5. Electron Spin Resonance (ESR) spectra of White Sands sample WS-6b. $30 \mathrm{mg}$ aliquots with zero and $100 \mathrm{~Gy}$ of external gamma dose. The spectra were recorded in dark. The corresponding spectra after sun bleaching the samples for $3 \mathrm{~h}$ are also included. (a) Sample exposed only to natural radiation (zero external dose). (b) Sample exposed to $100 \mathrm{~Gy}$ of external gamma irradiation. (c) Sample as in (a), exposed to sunlight for $3 \mathrm{~h}$. 
Table 2

Radiation-induced ESR centers in gypsum and their identification vis a vis previous assignments.

\begin{tabular}{lll}
\hline \multirow{2}{*}{ Designation of the center } & \multicolumn{2}{l}{ Identification of the center } \\
\cline { 2 - 3 } & Ikeya (1993) & Present work \\
\hline $\mathrm{G}_{1}$ & $\mathrm{SO}_{3}^{-}$ & $\mathrm{SO}_{3}^{-}$ \\
$\mathrm{G}_{2}$ & $\mathrm{CO}_{3}^{-} / \mathrm{O}_{2}^{3-}$ & $\mathrm{SO}_{4}^{-}$ \\
$\mathrm{G}_{3}$ & $\mathrm{CO}_{2}^{-}$ & $\mathrm{CO}_{2}^{-}$ \\
$\mathrm{G}_{4}$ & $\mathrm{O}_{2} \mathrm{H}$ & - \\
$\mathrm{C}$ & $\mathrm{SO}_{2}^{-}$ & $\mathrm{SO}_{2}^{-}$ \\
LS (Light sensitive) & - & Dynamic $\mathrm{O}_{3}^{-}$ \\
\hline
\end{tabular}

\subsection{2. $X R D$}

XRD of TD samples had stronger peaks due to $\mathrm{CaSO}_{3} .1 \frac{1}{2} \mathrm{H}_{2} \mathrm{O}$ and calcite as compared to gypsum. Some TD samples were completely formed gypsum crystals while others were powdery with
$\mathrm{CaSO}_{3} .1 / 2 \mathrm{H}_{2} \mathrm{O}$, suggesting these were at intermediate stages of gypsum formation. The WS samples were pure gypsum. Typical XRD spectrum is shown in Fig. 3.

\subsubsection{Fourier transform infrared spectra}

FT-IR spectra for White sands sample (WS-6b) showed absorption at $1115,1140,1630,2100-2200$ and $3550 \mathrm{~cm}^{-1}$. These are similar to those reported by Hentschel et al. (1985) and Laperche and Bigham (2002), Fig. 4. The FT-IR spectra from Thar samples (viz. TD-BJ-12 and TD-MILA-8) indicated additional features. Sample TD-MILA-8 had an absorption peak at $870 \mathrm{~cm}^{-1}$ and an absorption band at $1410-1460 \mathrm{~cm}^{-1}$ due to calcite. TD-BJ-12 showed absorption at $870 \mathrm{~cm}^{-1}$ and $1060 \mathrm{~cm}^{-1}$ indicating hydrated lime and $\mathrm{CaSO}_{3} \cdot 1 / 2 \mathrm{H}_{2} \mathrm{O}$ (Laperche and Bigham, 2002). Signals due to $\mathrm{CaSO}_{3} \cdot 1 / 2 \mathrm{H}_{2} \mathrm{O}$ and calcite were more intense than those from gypsum, and these could also be detected in XRD. Some of TD

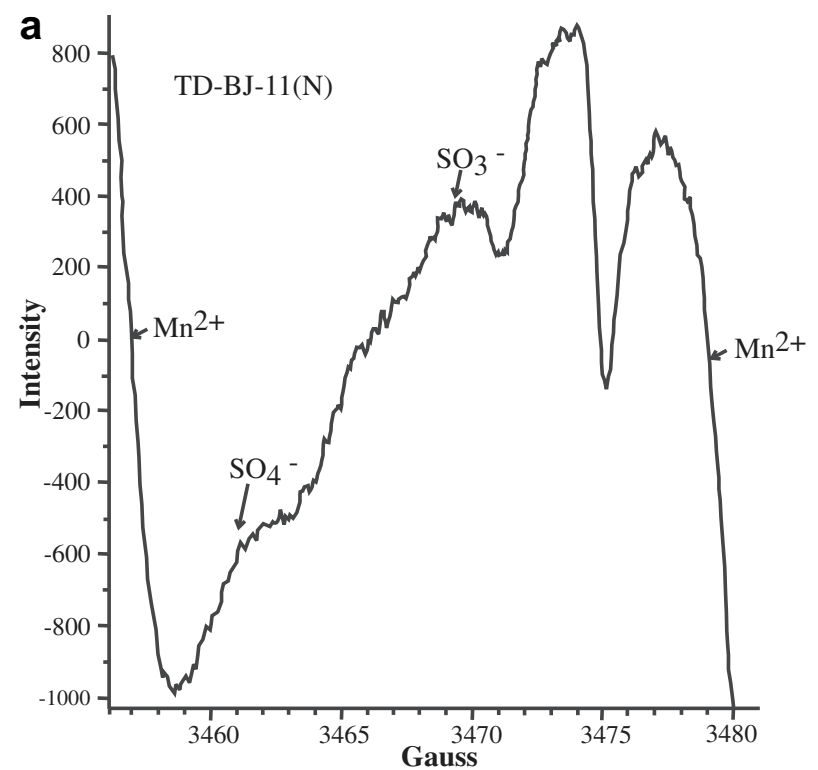

b
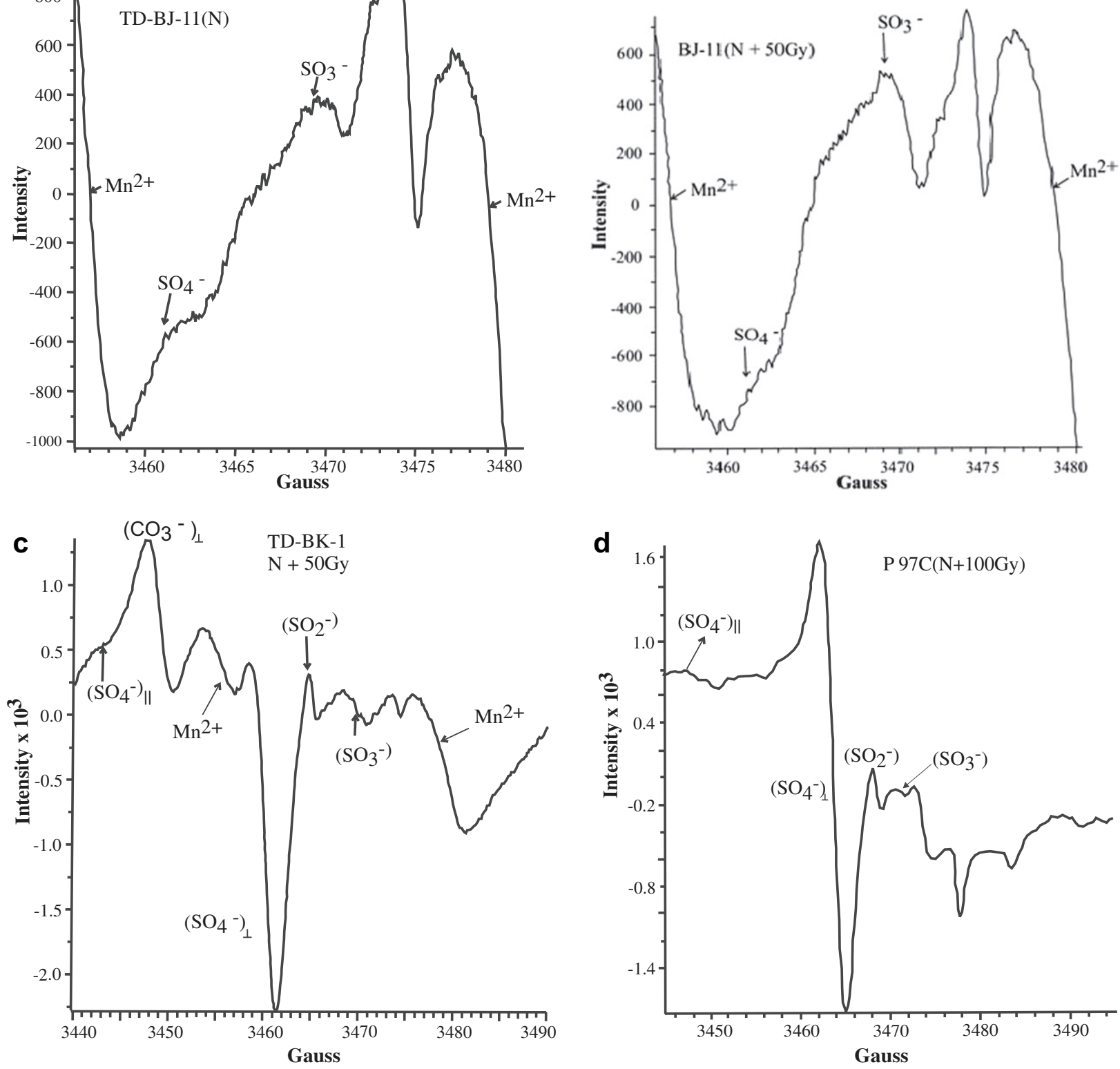

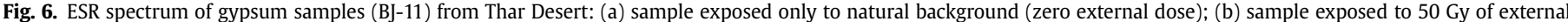

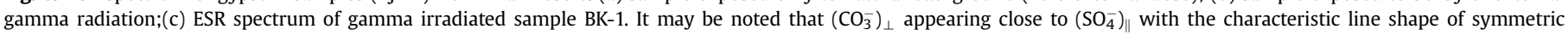
Lorentzian and, (d) ESR spectrum (N + $100 \mathrm{~Gy}$ ) of Australian sample (P97C). 
samples were pure crystalline gypsum suggesting that these represent completely formed gypsum whereas those of powdery variety contain $\mathrm{CaSO}_{3} \cdot 1 / 2 \mathrm{H}_{2} \mathrm{O}$, are at the intermediate stage of gypsum formation. FT-IR of the Australian samples indicated gypsum, calcite and hannebachite.

\subsection{ESR studies}

\subsubsection{White Sands}

The White Sands gypsum samples were well-sorted fine sands. Care was taken to ensure that the samples were not exposed to daylight during their, collection, transport, storage, gamma irradiation and ESR measurements. The ESR spectra for all the WS samples were similar and a typical spectrum is shown in Fig. 5a. Under identical operating conditions, the $\mathrm{S} / \mathrm{N}$ ratio and $\mathrm{Q}$ of the sample loaded cavity were higher for sun-bleached samples, possibly due to evaporation of surface moisture during sunlight exposure. These changes in $\mathrm{S} / \mathrm{N}$ and $\mathrm{Q}$ were duly accounted for.

The g-value of the ESR lines and associated centers are marked in Fig. 5(b). Intense lines at $g_{\|}=2.019$ and, $g_{\perp}=2.008$, together form the center $\mathrm{G}_{2}$. These g-values of $\mathrm{G}_{2}$ center agree well with those reported for $\mathrm{SO}_{4}^{-}$in alkaline earth sulfates (Dalvi et al., 1984; Seshagiri et al., 1988) but differ from the g-values of $\mathrm{CO}_{3}^{-}$reported by Ikeda and Ikeya (1992). The value of $g_{\perp}$ for $\mathrm{CO}_{3}^{-}$nearly coincides with that of $g_{\|}$of $\mathrm{SO}_{4}^{-}$. As discussed later, we assign the center $\mathrm{G}_{2}$ to $\mathrm{SO}_{4}^{-}$. The fact that this is a sulfate center in a sulfate matrix implies its utility for a direct dating of gypsum. Lines $G_{1}, G_{3}$ and $C$ (Table 2) are marked in Fig. 5(b,c).

The ESR data of the 'sunlight exposed' samples is shown in Fig. 5. To assess the changes that were caused by the sunlight exposure, we took the intensity ratios of signals corresponding to each species before and after exposure to the sunlight i.e.

$R=\left\{\mathrm{I}\left(\mathrm{SO}_{2}^{-}\right)\right.$after exposure $\left./ \mathrm{I}\left(\mathrm{SO}_{2}^{-}\right)_{\text {before exposure }}\right\}$

The ratios of intensities before and after sunlight exposure were measured for $\mathrm{SO}_{4}^{-}, \mathrm{SO}_{3}^{-}, \mathrm{G}_{3}, \mathrm{SO}_{2}^{-}$and "Light Sensitive' (LS) signal. They gave a clear insight in to the light induced changes. The ratio $\mathrm{R}$ was uniformly 1.2 to 1.3 for $\mathrm{SO}_{4}^{-}, \mathrm{SO}_{3}^{-}$and $\mathrm{G}_{3}$ due to changes in the $\mathrm{Q}$ value, suggesting that these centers were not affected by the light exposure. On the other hand, the ratio for $\mathrm{SO}_{2}^{-}$was 1.7 and 0.7 for LS. This was a clearly indication that the signal of ' $L S$ ' got depleted with light exposure, and there was an increase in $\mathrm{SO}_{2}^{-}$. The signal LS at $g=2.001$ can be identified with freely rotating $\mathrm{O}_{3}^{-}$(Marfunin, 1979; Prasad et al., 2005). This observation therefore suggests photo induced electron transfer between ozonide ion and $\mathrm{SO}_{2}$ in gypsum lattice. It is not possible to decide on whether the electron transfer is through conduction band or that involves an inter molecular charge transfer and this will have to be a matter of future study.

\subsubsection{Thar Desert}

The TD samples exhibited, 1 ) intense $\mathrm{Mn}^{2+}$ spectrum including its $\Delta_{\mathrm{mI}}= \pm 1$ forbidden transitions. The radiation-induced free radicals appeared between the central hyperfine lines (Fig. 6) and an overlap of the $\left(\mathrm{SO}_{4}\right)_{\perp}$ line with the low field line of $\Delta_{\mathrm{mI}}= \pm 1$ doublet around 3455G. Fig. 6a,b shows the ESR spectrum of sample as received $(\mathrm{N})$ and the same sample to a laboratory gamma dose of $50 \mathrm{~Gy}(\mathrm{~N}+50 \mathrm{~Gy}) ; 2)$ In TD-BK-1, an intense line due to $\left(\mathrm{CO}_{3}^{-}\right)_{\perp}$ at $g=2.016$ with the characteristics of a perpendicular line was also observed (Fig. 6c) suggesting that the line $\mathrm{G}_{2}$ was not due to $\mathrm{CO}_{3}^{-} ; 3$ ) The TD samples with hannebachite did not have $\mathrm{SO}_{2}^{-}$and the $\mathrm{SO}_{3}^{-}$ signal was more intense compared to $\mathrm{SO}_{4}^{-}$, suggesting that for such samples $\mathrm{SO}_{3}^{-}$was the only usable center, 4) for powdery TD samples, interference from $\mathrm{Mn}^{2+}$ ions precluded the use of the $\mathrm{SO}_{4}^{-}$ signal.

Compared to the WS samples, the TD samples with hannebachite did not have $\mathrm{SO}_{2}^{-}$signal, and the $\mathrm{SO}_{3}^{-}$signal is more intense compared to $\mathrm{SO}_{4}^{-}$. This is more apparent at higher doses, suggesting that for the TD samples, $\mathrm{SO}_{3}^{-}$can be the only center that can be used for the dating. Location of $\mathrm{Mn}^{2+}$, either in calcite or gypsum/hannebachite, cannot be ascertained. Coexistence of calcium carbonate, gypsum and hannebachite together with significant amount of $\mathrm{Mn}^{2+}$ impurity reflects the geochemical environment from which gypsum was precipitated. We surmise that this was an anoxic environment, as reflected in the lower oxidation states of $\mathrm{Mn}$ and sulfur. The ESR signal of $\mathrm{Mn}^{2+}$ is of no direct relevance to geochronology except for that it obscures the signals due to $\mathrm{SO}_{4}^{-}$. Table 3 provides a summary of the FT-IR and ESR results obtained in gypsum samples with key ESR centers used for dating.

\subsubsection{Australian gypsum}

Australian samples had a strong $\mathrm{SO}_{4}^{-}$ESR signal which was used for analysis. The ESR spectrum for AS samples is typical of gypsum (Fig. 6d).

Table 3

A summary of the FT-IR and ESR results obtained in gypsum samples with key ESR centers used for dating.

\begin{tabular}{|c|c|c|c|c|}
\hline S. No. & $\begin{array}{l}\text { Sample } \\
\text { No. }\end{array}$ & $\begin{array}{l}\text { Sample type } \\
\& \text { origin of } \\
\text { sample }\end{array}$ & $\begin{array}{l}\text { Constituents of } \\
\text { the sample } \\
\text { (from FT-IR) }\end{array}$ & $\begin{array}{l}\text { Key, radiation } \\
\text {-induced } \\
\text { ESR centers }\end{array}$ \\
\hline 1 & $6 b$ & White sand & Only gypsum & $\begin{array}{l}\mathrm{SO}_{4}^{-} \text {(strong) } \\
\mathrm{SO}_{3}^{-} \text {(v.weak) } \\
\mathrm{SO}_{2}^{-}\end{array}$ \\
\hline 2 & $4 b$ & White sand & Only gypsum & $\begin{array}{l}\mathrm{SO}_{4}^{-} \text {(strong) } \\
\mathrm{SO}_{3}^{-} \text {(v.weak) } \\
\mathrm{SO}_{2}^{-}\end{array}$ \\
\hline 3 & $2 b$ & White sand & Only gypsum & $\begin{array}{l}\mathrm{SO}_{4}^{-} \text {(strong) } \\
\mathrm{SO}_{3}^{-} \text {(v.weak) } \\
\mathrm{SO}_{2}^{-}\end{array}$ \\
\hline 4 & $6 b$ & White sand & Only gypsum & $\begin{array}{l}\mathrm{SO}_{4}^{-} \text {(strong) } \\
\mathrm{SO}_{3}^{-} \text {(v.weak) } \\
\mathrm{SO}_{2}^{-}\end{array}$ \\
\hline 5 & MILA-8 & Thar Desert & Gypsum + Hydrated lime & $\begin{array}{l}\mathrm{SO}_{4}^{-} \text {(weak) } \\
\mathrm{SO}_{3}^{-} \text {(strong) }\end{array}$ \\
\hline 6 & $\mathrm{BJ}-12$ & Thar Desert & $\begin{array}{l}\text { Gypsum }+\mathrm{CaSO}_{3} 0.5 \mathrm{H}_{2} \mathrm{O} \\
+ \text { Hydrated lime }\end{array}$ & $\begin{array}{l}\mathrm{SO}_{4}^{-} \text {(weak) } \\
\mathrm{SO}_{3}^{-} \text {(strong) }\end{array}$ \\
\hline 7 & BJ-11 & Thar Desert & $\begin{array}{l}\mathrm{CaSO}_{3} 0.5 \mathrm{H}_{2} \mathrm{O}+\text { Hydrated } \\
\text { lime + Gypsum }\end{array}$ & $\begin{array}{l}\mathrm{SO}_{4}^{-} \text {(strong) } \\
\mathrm{SO}_{3}^{-} \text {(v.weak) }\end{array}$ \\
\hline 8 & $\mathrm{NACH}-1$ & Thar Desert & Gypsum + Hydrated lime & $\begin{array}{l}\mathrm{SO}_{4}^{-} \text {(weak) } \\
\mathrm{SO}_{3}^{-} \text {(strong) }\end{array}$ \\
\hline 9 & $\mathrm{NACH}-3$ & Thar Desert & $\begin{array}{l}\text { Gypsum }+\mathrm{CaSO}_{3} 0.5 \mathrm{H}_{2} \mathrm{O} \\
+ \text { Hydrated lime }\end{array}$ & $\begin{array}{l}\mathrm{SO}_{4}^{-} \text {(weak) } \\
\mathrm{SO}_{3}^{-} \text {(strong) }\end{array}$ \\
\hline 10 & $\mathrm{NACH}-4$ & Thar Desert & Gypsum + Hydrated lime & $\begin{array}{l}\mathrm{SO}_{4}^{-} \text {(weak) } \\
\mathrm{SO}_{3}^{-} \text {(strong) }\end{array}$ \\
\hline 11 & $920802 / 16$ & Australia & Only gypsum & $\begin{array}{l}\mathrm{SO}_{4}^{-} \text {(strong) } \\
\mathrm{SO}_{3}^{-} \text {(v.weak) }\end{array}$ \\
\hline 12 & P96k & Australia & Gypsum + Calcite & $\begin{array}{l}\mathrm{SO}_{4}^{-} \text {(strong) } \\
\mathrm{SO}_{3}^{-} \text {(v.weak) }\end{array}$ \\
\hline 13 & P97C & Australia & - & $\begin{array}{l}\mathrm{SO}_{4}^{-} \text {(strong) } \\
\mathrm{SO}_{3}^{-} \text {(weak) }\end{array}$ \\
\hline 14 & $89109 / 2$ & Australia & $\begin{array}{l}\text { Gypsum + CaSO3 } 0.5 \mathrm{H} 2 \mathrm{O} \\
+ \text { Calcite }\end{array}$ & $\begin{array}{l}\mathrm{SO}_{4}^{-} \text {(strong) } \\
\mathrm{SO}_{3}^{-} \text {(v.weak) }\end{array}$ \\
\hline 15 & $89109 / 8$ & Australia & $\begin{array}{l}\text { Gypsum + CaSO3 } 0.5 \mathrm{H} 2 \mathrm{O} \\
+ \text { Calcite }\end{array}$ & $\begin{array}{l}\mathrm{SO}_{4}^{-} \text {(strong) } \\
\mathrm{SO}_{3}^{-} \text {(v.weak) }\end{array}$ \\
\hline 16 & 89 109/10 & Australia & - & $\begin{array}{l}\mathrm{SO}_{4}^{-} \text {(strong) } \\
\mathrm{SO}_{3}^{-} \text {(v.weak) }\end{array}$ \\
\hline
\end{tabular}



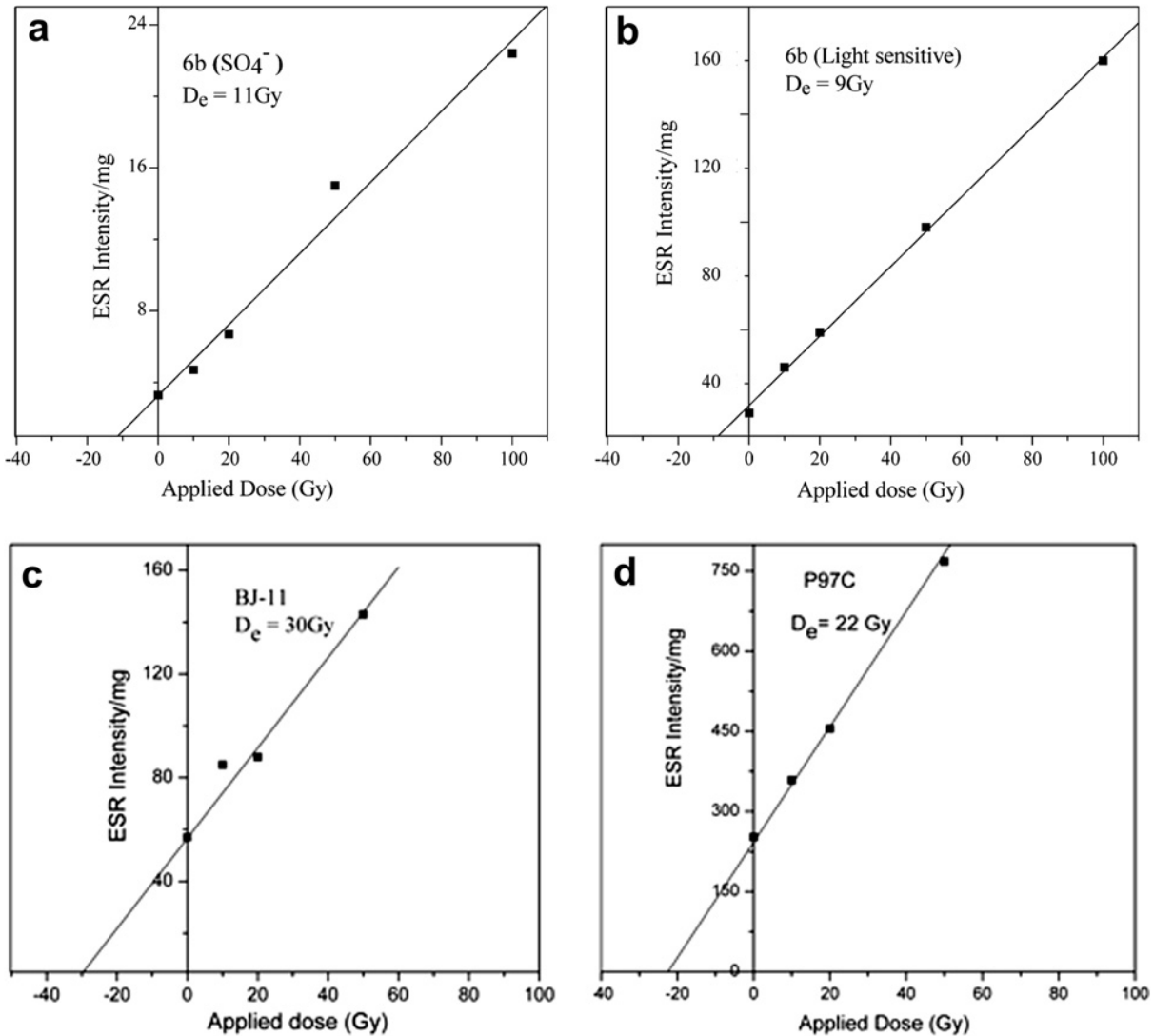

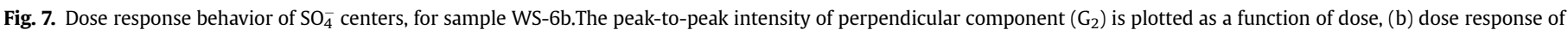

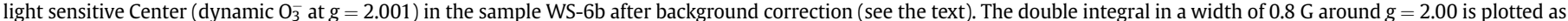

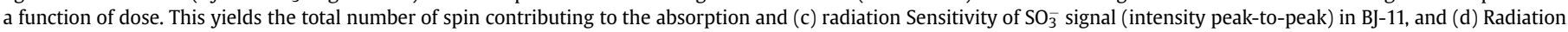
response of Australian sample (P97C).

Table 4

Details of ESR signals, ESR paleodose, and radioactive data. Computed ESR ages and control BLSL ages are also given for comparison.

\begin{tabular}{|c|c|c|c|c|c|c|c|c|c|c|}
\hline $\begin{array}{l}\text { Dating } \\
\text { signal }\end{array}$ & Sample & $\begin{array}{l}\text { Sample } \\
\text { type }\end{array}$ & $\begin{array}{l}\mathrm{U} \\
\text { (ppm) }\end{array}$ & $\begin{array}{l}\text { Th } \\
\text { (ppm) }\end{array}$ & $\begin{array}{l}\mathrm{K} \\
(\%)\end{array}$ & $\begin{array}{l}\text { Cosmic ray } \\
(\mu \mathrm{Gy} / \mathrm{a})\end{array}$ & $\begin{array}{l}\text { ESR De } \\
(G y)\end{array}$ & $\begin{array}{l}\text { Dose rate } \\
(\mathrm{Gy} / \mathrm{ka})\end{array}$ & $\begin{array}{l}\text { ESR age } \\
\text { (ka) }\end{array}$ & $\begin{array}{l}\text { Luminescence } \\
\text { age (ka) }\end{array}$ \\
\hline \multirow[t]{14}{*}{$\mathrm{SO}_{4}^{-}$} & WS-1b & Gypsum sand & $0.05 \pm 0.004$ & $0.21 \pm 0.15$ & $0.021 \pm 0.002$ & $197 \pm 19$ & $0.7 \pm 0.07$ & $0.3 \pm 0.03$ & $2.2 \pm 0.3$ & $2.1 \pm 0.2$ \\
\hline & WS-2b & Gypsum sand & $0.13 \pm 0.00$ & $0.00 \pm 0.00$ & $0.020 \pm 0.002$ & $168 \pm 16$ & $1.0 \pm 0.1$ & $0.3 \pm 0.03$ & $3.4 \pm 0.4$ & $3.3 \pm 0.2$ \\
\hline & WS-4b & Gypsum Sand & $0.30 \pm 0.10$ & $0.06 \pm 0.06$ & $0.050 \pm 0.013$ & $126 \pm 12$ & $2.8 \pm 0.3$ & $0.6 \pm 0.08$ & $4.6 \pm 0.6$ & $4.3 \pm 0.4$ \\
\hline & WS-6b & Gypsum sand & $1.49 \pm 0.10$ & $0.20 \pm 0.38$ & $0.10 \pm 0.05$ & $97 \pm 9$ & $11.0 \pm 1.0$ & $2.0 \pm 0.2$ & $5.5 \pm 1.2$ & $5.2 \pm 0.4$ \\
\hline & TD-NACH-4 & Crystalline & $2.1 \pm 0.4$ & $3.7 \pm 0.4$ & $0.40 \pm 0.03$ & $150 \pm 30$ & $20.0 \pm 1.5$ & $3.4 \pm 0.3$ & $5.8 \pm 0.9$ & $>2.4$ or $<10.4$ \\
\hline & TD-NACH-4 & Crystalline & $2.1 \pm 0.4$ & $3.7 \pm 0.4$ & $0.40 \pm 0.03$ & $150 \pm 30$ & $20.0 \pm 2.0$ & $3.5 \pm 0.3$ & $5.8 \pm 0.9$ & $>2.4$ or $<10.4$ \\
\hline & TD-MOH-3 & Crystalline & $1.2 \pm 0.2$ & $0.9 \pm 0.7$ & $0.55 \pm 0.03$ & $150 \pm 30$ & $13.0 \pm 1.3$ & $2.1 \pm 0.2$ & $6.1 \pm 0.8$ & $>5.8$ or $<10.1$ \\
\hline & TD-BK-1 & Crystalline & $1.3 \pm 0.2$ & $1.1 \pm 0.8$ & $0.61 \pm 0.04$ & $150 \pm 30$ & $35.0 \pm 3.0$ & $2.3 \pm 0.3$ & $15.5 \pm 2.2$ & $>7.0$ \\
\hline & $920802 / 16$ & Crystalline & $0.12 \pm 0.04$ & $0.37 \pm 0.16$ & $1.1 \pm 0.01$ & $150 \pm 30$ & $117.0 \pm 12.0$ & $1.4 \pm 0.1$ & $86.0 \pm 10.0$ & $88.0 \pm 4.0$ \\
\hline & P96 K & Crystalline & $0.05 \pm 0.01$ & $0.16 \pm 0.05$ & $0.6 \pm 0.04$ & $150 \pm 30$ & $33.0 \pm 3.0$ & $0.80 \pm 0.6$ & $37.0 \pm 5.0$ & $25-40 \#$ \\
\hline & P97C & Crystalline & $0.05 \pm 0.01$ & $0.17 \pm 0.08$ & $0.8 \pm 0.05$ & $150 \pm 30$ & $22.0 \pm 2.0$ & $1.0 \pm 0.7$ & $21.1 \pm 2.0$ & $25-40 \#$ \\
\hline & $89109 / 2$ & Crystalline & $0.12 \pm 0.01$ & $0.09 \pm 0.06$ & $0.6 \pm 0.04$ & $150 \pm 30$ & $13.0 \pm 1.3$ & $1.0 \pm 0.3$ & $12.0 \pm 2.0$ & $15.0 \pm 2.0$ \\
\hline & $89109 / 8$ & Crystalline & $0.15 \pm 0.01$ & $0.10 \pm 0.04$ & $0.5 \pm 0.03$ & $150 \pm 30$ & $45.0 \pm 5.0$ & $0.50 \pm 0.03$ & $87.0 \pm 3.0$ & $70-80$ \\
\hline & $89109 / 10$ & Crystalline & $0.24 \pm 0.02$ & $0.14 \pm 0.10$ & $0.2 \pm 0.02$ & $150 \pm 30$ & $44.0 \pm 4.0$ & $0.60 \pm 0.01$ & $87.0 \pm 10$ & $70-80$ \\
\hline \multirow[t]{6}{*}{$\mathrm{SO}_{3}^{-}$} & TD-NACH-3 & Granular & $1.8 \pm 0.3$ & $2.3 \pm 0.3$ & $0.22 \pm 0.02$ & $150 \pm 30$ & $33.0 \pm 3.0$ & $2.6 \pm 0.2$ & $12.7 \pm 1.8^{\mathrm{a}}$ & $<10.4$ \\
\hline & TD-CBR-3 & Powdery & $1.7 \pm 0.3$ & $5.2 \pm 0.4$ & $0.61 \pm 0.04$ & $150 \pm 30$ & $67.0 \pm 7.0$ & $3.7 \pm 0.3$ & $18.3 \pm 2.4^{\mathrm{a}}$ & $>3.0$ or $<5.1$ \\
\hline & TD-CBR-5 & Powdery & $1.8 \pm 0.3$ & $3.8 \pm 0.9$ & $0.58 \pm 0.03$ & $150 \pm 30$ & $38.0 \pm 4.0$ & $3.4 \pm 0.3$ & $11.1 \pm 1.6^{\mathrm{a}}$ & $>3.0$ or $<5.1$ \\
\hline & TD-BJ-4 & Granular & $2.3 \pm 0.6$ & $2.1 \pm 0.3$ & $0.60 \pm 0.04$ & $150 \pm 30$ & $37.0 \pm 3.0$ & $3.4 \pm 0.5$ & $11.0 \pm 2.1^{\mathrm{a}}$ & $>3.8$ or $<2.0$ \\
\hline & TD-BJ-11 & Powdery & $2.3 \pm 0.6$ & $1.9 \pm 0.3$ & $0.60 \pm 0.04$ & $150 \pm 30$ & $30.0 \pm 3.0$ & $3.4 \pm 0.5$ & $8.7 \pm 1.5^{a}$ & $\leq 3.1$ \\
\hline & TD-BJ-12 & Powdery & $2.0 \pm 0.3$ & $1.1 \pm 0.6$ & $0.57 \pm 0.03$ & $150 \pm 30$ & $35.0 \pm 3.0$ & $2.9 \pm 0.3$ & $12.2 \pm 1.4^{\mathrm{a}}$ & $\leq 3.1$ \\
\hline \multirow[t]{2}{*}{$\mathrm{O}_{3}^{-}$} & WS-1b & Gypsum sand & $0.05 \pm 0.004$ & $0.21 \pm 0.15$ & $0.021 \pm 0.002$ & $197 \pm 19$ & $0.60 \pm 0.05$ & $0.3 \pm 0.03$ & $1.8 \pm 0.3$ & $2.1 \pm 0.2$ \\
\hline & WS-6b & Gypsum sand & $1.49 \pm 0.10$ & $0.20 \pm 0.38$ & $0.10 \pm 0.05$ & $97 \pm 9$ & $9.0 \pm 0.09$ & $2.0 \pm 0.2$ & $4.5 \pm 1.1$ & $5.2 \pm 0.4$ \\
\hline
\end{tabular}

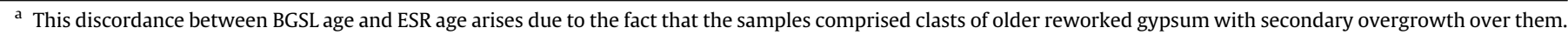
Being a volume signal, ESR therefore represents a bulk age and hence is older than the BGSL age. BGSL ages represent the date of fluvial transport of older gypsum. 


\subsection{Radiation response and dating analysis}

\subsubsection{White Sands}

Fig. 7a and b show the dose response of $\mathrm{SO}_{4}^{-}$and the light sensitive $\mathrm{O}_{3}^{\overline{-}}$ center for WS-6b. The radiation response of the light sensitive center was based on the double integral of the signal of width $( \pm 0.85 \mathrm{G})$ at $g=2.001$. Double integral with base line correction gave a linear dose response with reduced scatter compared to the peak-to-peak method. Both these centers yielded similar paleodoses, $\left(D_{e}\right)$.

\subsubsection{Thar Desert samples}

Compared to the gypsum crystals, $\mathrm{SO}_{4}^{-}$signal could not be used for powdery TD-samples due to interference by $\mathrm{Mn}^{2+}$. The dose response of the $\mathrm{SO}_{3}^{-}$line intensity was linear up to $350 \mathrm{~Gy}$ and was used after confirming that this line was not due to thermal decomposition of other radical(s). Known relative intensities of $\mathrm{SO}_{4}^{-}$ and $\mathrm{SO}_{3}^{-}$in anhydrite and pure gypsum, enabled the conclusion that the $\mathrm{SO}_{3}^{-}$signal in hannebachite-rich TD samples, originated from the sulfite region and hence was suitable for dating. Here, the presence of an intense $\mathrm{SO}_{3}^{-}$signal obscured the measurement of LS. The location of $\mathrm{Mn}^{2+}$ ions, either in calcite or gypsum/hannebachite could not be ascertained, however coexistence of $\mathrm{CaCO}_{3}$, gypsum and hannebachite together with significant $\mathrm{Mn}^{2+}$ suggests an anoxic environment during gypsum precipitation.

A typical radiation response and $\mathrm{D}_{\mathrm{e}}$ of the $\mathrm{SO}_{3}^{-}$(TD-BJ-11) of $\mathrm{SO}_{3}^{-}$ center in is shown in Fig. $7 \mathrm{c}$. The respective $\mathrm{D}_{\mathrm{e}}$ values are tabulated
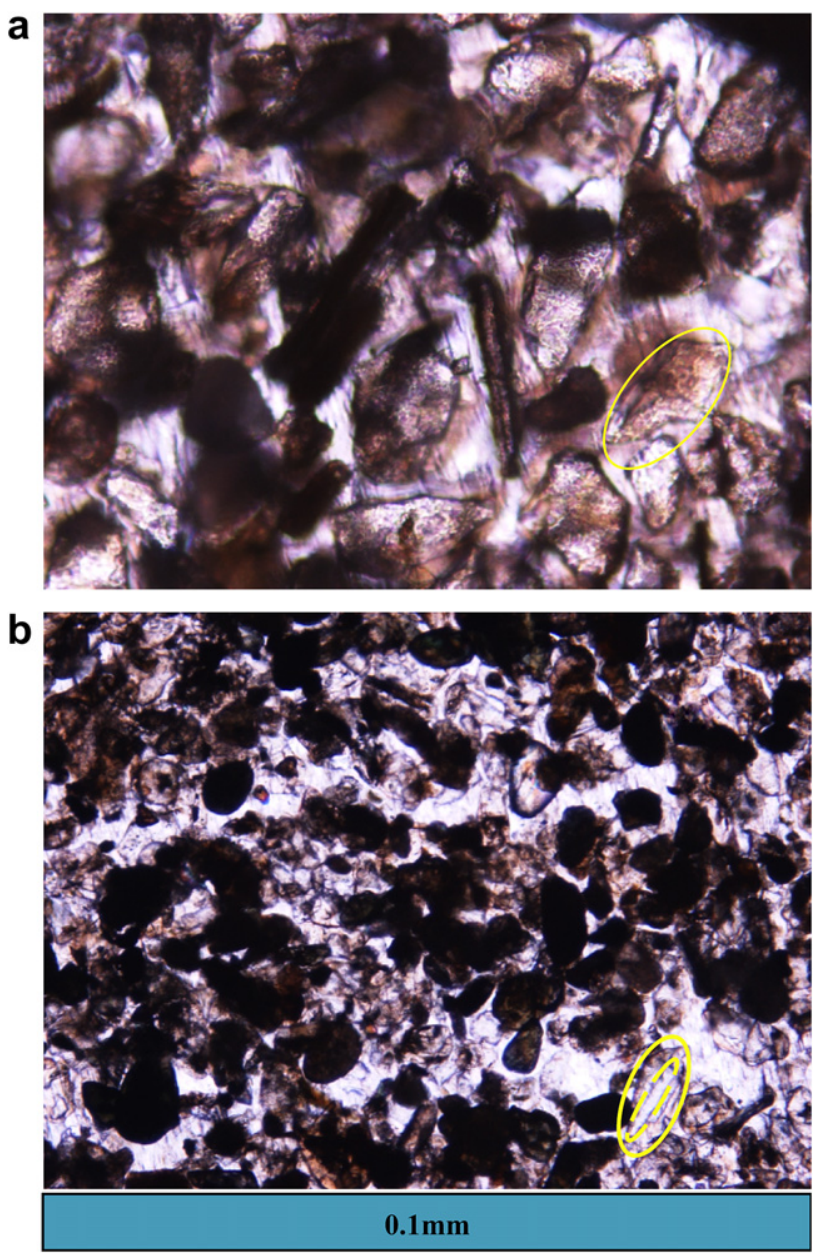

Fig. 8. (a, b) Thin section of the powdery gypsum, the region of overgrowth is shown in circle and the non re-crystallized area is shown with the doted circle (inner circle). in Table 4. Ideally, the dose response curve should be fitted to a saturating exponential function, but limited on the data points and the observation that the overall growth curve was linear up to $750 \mathrm{~Gy}$, suggested that for absorbed doses ( $\mathrm{D}_{\mathrm{e}}$ 's) of $<60 \mathrm{~Gy}$, a linear extrapolation was a reasonable approximation. Comparison of the same data fitted with linear and saturating exponential functions for samples gave $\mathrm{D}_{\mathrm{e}}$ values within a $1 \sigma$ limit (3-5\%). As an abundant precaution we would however, recommend the paleodose using linear extrapolation as being an upper bound. These samples were also examined for a photosensitive signal however the presence of intense $\mathrm{SO}_{3}^{-}$signal close to $\mathrm{LS}$, made it difficult to identify and measure the intensity of this center and hence was not pursued. $\mathrm{D}_{\mathrm{e}}$ from Blue Light Stimulated Luminescence (BLSL) measurements on syn-sedimentary quartz grains is included for comparison.

The cases of six anomalous ESR ages as compared to BGSL ages initially proved enigmatic, but their origin was eventually understood from thin-section studies, that indicated the samples comprised multi-phase gypsum such that older gypsum had a overgrowth of later formed gypsum (Fig. 8). This implied that the ESR signal reflected an average age of the older gypsum derived from a pre existing formation and the younger gypsum and hence had an older apparent age compared to the optical age of synsedimentary quartz. Thus, we suggest that for a reliable dating of
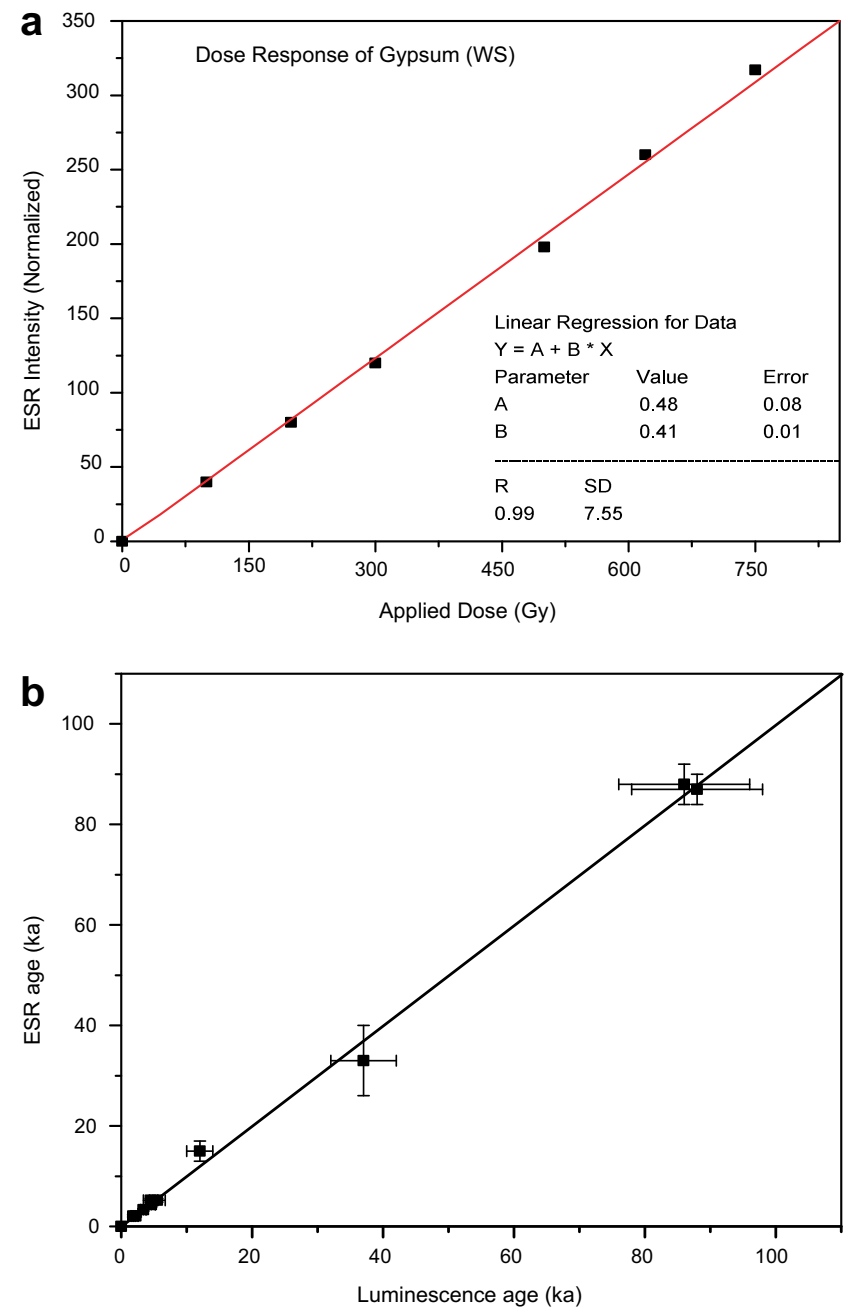

Fig. 9. (a) Dose behavior of the crystalline gypsum, the linearity of dose up to $750 \mathrm{~Gy}$ is shown and (b) comparison between ESR and Luminescence ages (control ages are only plotted in this figure). 
Table 5

Contribution of the internal and external doses.

\begin{tabular}{|c|c|c|c|}
\hline Sample & Contributors & Internal dose & External dose \\
\hline WS-1b & $\begin{array}{l}\alpha \\
\beta \\
\gamma+\cos \end{array}$ & $\begin{array}{l}74 \pm 28 \\
31 \pm 5\end{array}$ & $\begin{aligned} 0 & \pm 0 \\
0 & \pm 0 \\
217 & \pm 20\end{aligned}$ \\
\hline WS-2b & $\begin{array}{l}\alpha \\
\beta \\
\gamma+\cos \end{array}$ & $\begin{array}{l}90 \pm 0 \\
35 \pm 2\end{array}$ & $\begin{aligned} 0 & \pm 0 \\
0 & \pm 0 \\
185 & \pm 16\end{aligned}$ \\
\hline TD-NACH-4 & $\begin{array}{l}\alpha \\
\beta \\
\gamma+\cos \end{array}$ & $\begin{aligned} 2143 & \pm 288 \\
742 & \pm 65\end{aligned}$ & $\begin{aligned} 0 & \pm 0 \\
0 & \pm 0 \\
561 & \pm 57\end{aligned}$ \\
\hline TD-MOH-3 & $\begin{array}{l}\alpha \\
\beta \\
\gamma+\cos .\end{array}$ & $\begin{array}{c}1001 \pm 190 \\
650 \pm 43\end{array}$ & $\begin{aligned} 0 & \pm 0 \\
0 & \pm 0 \\
396 & \pm 48\end{aligned}$ \\
\hline TD-BK-1 & $\begin{array}{l}\alpha \\
\beta \\
\gamma+\cos .\end{array}$ & $\begin{array}{c}1107 \pm 203 \\
720 \pm 50\end{array}$ & $\begin{aligned} 0 & \pm 0 \\
0 & \pm 0 \\
4250 & \pm 52\end{aligned}$ \\
\hline $9208202 / 16$ & $\begin{array}{l}\alpha \\
\beta \\
\gamma+\cos .\end{array}$ & $\begin{array}{l}152 \pm 41 \\
924 \pm 82\end{array}$ & $\begin{aligned} 0 & \pm 0 \\
0 & \pm 0 \\
383 & \pm 40\end{aligned}$ \\
\hline P96K & $\begin{array}{l}\alpha \\
\beta \\
\gamma+\cos .\end{array}$ & $\begin{array}{r}64 \pm 12 \\
500 \pm 33\end{array}$ & $\begin{aligned} 0 & \pm 0 \\
0 & \pm 0 \\
274 & \pm 32\end{aligned}$ \\
\hline P97C & $\begin{array}{l}\alpha \\
\beta \\
\gamma+\cos .\end{array}$ & $\begin{array}{r}66 \pm 16 \\
663 \pm 41\end{array}$ & $\begin{aligned} 0 & \pm 0 \\
0 & \pm 0 \\
312 & \pm 34\end{aligned}$ \\
\hline $89109 / 2$ & $\begin{array}{l}\alpha \\
\beta \\
\gamma+\cos .\end{array}$ & $\begin{array}{l}100 \pm 13 \\
509 \pm 33\end{array}$ & $\begin{aligned} 0 & \pm 0 \\
0 & \pm 0 \\
295 & \pm 33\end{aligned}$ \\
\hline TD-BJ-11 & $\begin{array}{l}\alpha \\
\beta \\
\gamma+\cos .\end{array}$ & $\begin{array}{c}1940 \pm 421 \\
882 \pm 94\end{array}$ & $\begin{aligned} 0 & \pm 0 \\
0 & \pm 0 \\
544 & \pm 68\end{aligned}$ \\
\hline
\end{tabular}

authigenic minerals identification of multiple phases using thin section studies is a desirable prerequisite (Kailath et al., 2000).

\subsubsection{Australian samples}

Samples AS had a strong $\mathrm{SO}_{4}^{-}$ESR signal and this was used for analysis. The dose response of $\mathrm{SO}_{4}^{-}$is shown in Fig. 7d. These are compared with luminescence ages from Magee et al. (2004) and unpublished data.

Table 4 provides the ESR and OSL ages, Fig. 9a provides the typical dose response curve of crystalline gypsum and linear growth up to $750 \mathrm{~Gy}$ is seen. Fig. 9b provides ages and their comparison with control ages, suggesting that the signals are stable at least up to $100 \mathrm{ka}$. Table 5 provides the contribution of internal and external doses.

\section{Discussion}

\subsection{Dating aspects: long term stability of dating centers}

For dating, longterm stability of the radiation sensitive radical ions is a key prerequisite. The thermal stability of the radiationinduced centers or their isothermal decay characteristics cannot be investigated in gypsum, due to water loss at $90^{\circ}-120^{\circ} \mathrm{C}$ and then at $180{ }^{\circ} \mathrm{C}$, when the sample loses its integrity (loss of second (0.5) water). It is therefore not possible to derive at the lifetime of the traps by constructing Arrhenius plots. The $\mathrm{SO}_{4}^{-}$radical ion was used for dating WS samples but the presence of $\mathrm{Mn}^{2+}$ obscured its use for TD samples.

An interference free signal in TD samples is $\mathrm{SO}_{3}^{-}$, however its thermal behavior is different in hannebachite-rich TD samples compared to the WS. This suggests that the nature of $\mathrm{SO}_{3}^{-}$species is different in the two sets of samples. The intensity of $\mathrm{SO}_{3}^{-}$signal in
WS increased with temperature, similar to that reported by earlier workers in anhydrite and gypsum (Dalvi et al., 1984; Seshagiri et al., 1988; Kasuya et al., 1991) and it marginally decreased in the case of TD samples. This change was reversible suggesting that $\mathrm{SO}_{3}^{-}$is both thermally stable and that its number density does not vary with temperature. Kasuya et al. (1991) also reported that the intensity of $\mathrm{SO}_{3}^{-}$increased with temperature, similar to that in anhydrous alkaline earth sulfates, as reported by Dalvi et al. (1984) and Seshagiri et al. (1988). The mechanism of this anomalous increase of $\mathrm{SO}_{3}^{-}$with temperature has not been addressed so far.

As the TD samples contained significant amount of sulfite, it is therefore reasonable to assume that this center is from sulfite rich region. $\mathrm{SO}_{3}$ in a sulfite environment would be different from $\mathrm{SO}_{3}$ as a point defect in sulfate matrix. We anticipate that the stability would be very different. The $\mathrm{SO}_{3}$ center as a point defect in sulfate matrix should act as an efficient electron trap (electrons trapped at oxygen vacancy). The electron trapping by $\mathrm{SO}_{3}$, would leads to the formation of diamagnetic $\mathrm{SO}_{3}^{2-}$ with paramagnetic $\mathrm{SO}_{3}^{-}$as an intermediate. The radical $\mathrm{SO}_{3}^{2-}$ has the electronic configuration $6 \mathrm{a}^{* 2}$ resulting in diamagnetic ${ }^{1} \mathrm{~A}$, state (Marfunin, 1979). The anti-bonding nature of electrons would add to the repulsive force between $\mathrm{S}^{4+}$ and $\mathrm{O}^{2-}$ (in $\mathrm{SO}_{3}^{2-}$ ), increasing $\mathrm{S}-\mathrm{O}$ bond distance considerably. Therefore $\mathrm{SO}_{3}^{2-}$ would produce significant local strain in alkaline earth sulfate lattice. This strain could be released only by the loss of electrons and hence it becomes a shallow electron trap, which could probably be thermally ionized around $100-150{ }^{\circ} \mathrm{C}$, generating $\mathrm{SO}_{3}^{-}$radicals. Such a case would not occur for $\mathrm{SO}_{3}^{2-}$ in a sulfite matrix, where it would be a hole trap, and it hence would not produce any strain in a lattice where it is a major constituent. Therefore, $\mathrm{SO}_{3}$ in sulfite matrix is a case more analogous to $\mathrm{SO}_{4}^{-}$in a sulfate matrix and it can be used for dating the samples that contain hannebachite.

Circumstantial evidence also indicates that the centers are stable over a long period at room temperature. The line $G_{2}$ was used for dating by Ikeda and Ikeya (1992) and Mathew et al. (2004). The ages estimated using this signal for different samples ranged from $200 \mathrm{ka}$ to $70 \mathrm{ka}$. Though these ages are not compared with any standards, the age of 70 ka does indicate that the centers are reasonably stable. Ikeda and Ikeya (1992) assigned this signal to $\mathrm{CO}_{3}^{-}$, which we believe is due to $\mathrm{SO}_{4}^{-}$for the reasons mentioned earlier as also due to the observation that the $\mathrm{g}_{\|}$value of $\mathrm{SO}_{4}^{-}$is nearly equal to $\mathrm{g}_{\perp}$ value of $\mathrm{CO}_{3}^{-}$ and vice versa. Interestingly, $g_{\|}>g_{\perp}$ for $\mathrm{SO}_{4}^{-}$and $g_{\perp}>g_{\|}$for $\mathrm{CO}_{3}^{-}$. Simple visual examination of $G_{2}$ shows that $g_{\|}>g_{\perp}$ and hence it implies that it it cannot be assigned to carbonate radical. The gvalues for $\mathrm{G}_{2}\left(g_{\|}=2.0196, g_{\perp}=2.008\right)$ agree with those reported for $\mathrm{SO}_{4}^{-}$. We refer to Danby et al. (1982) for g-values for $\mathrm{SO}_{4}^{-}$at site-II in $\mathrm{CaSO}_{4}$.

This species being an integral part of the major matrix gives a direct method for geochronology of gypsum. The thermal activation energy of $\mathrm{SO}_{4}^{-}$destruction in anhydrous alkaline earth sulfates is around $1 \mathrm{eV}$, with frequency factors varying between $10^{11}$ and $10^{13}$ (Dalvi et al., 1984; Seshagiri et al., 1988). These values suggest a short lifetime for this center. However, consistency of ages based on this center in White Sands samples with BLSL ages on syn-sedimentary quartz, suggests that the stability of the signal should be $>100 \mathrm{ka}$. This estimate is based on a comparison of gypsum ESR ages with the control ages. This implies that either the frequency factors based on thermoluminescence measurements are significantly lower than those reported (Dalvi et al., 1984), or the activation energy of $\mathrm{SO}_{4}^{-}$in gypsum is significantly higher compared to that in anhydrite. We consider this as plausible as unlike in anhydrite, the water molecules in gypsum would contribute to higher stability of the $\mathrm{SO}_{4}^{-}$center through hydrogen bonding between sulfate oxygen and the water proton (Marfunin, 1979). In the ESR spectra of White Sands samples at $77 \mathrm{~K}$, the parallel component of $\mathrm{SO}_{4}^{-}$was significantly broader than that reported in $\mathrm{CaSO}_{4}$ at $77 \mathrm{~K}$ (Dalvi et al.,1984; Seshagiri et al., 1988). 


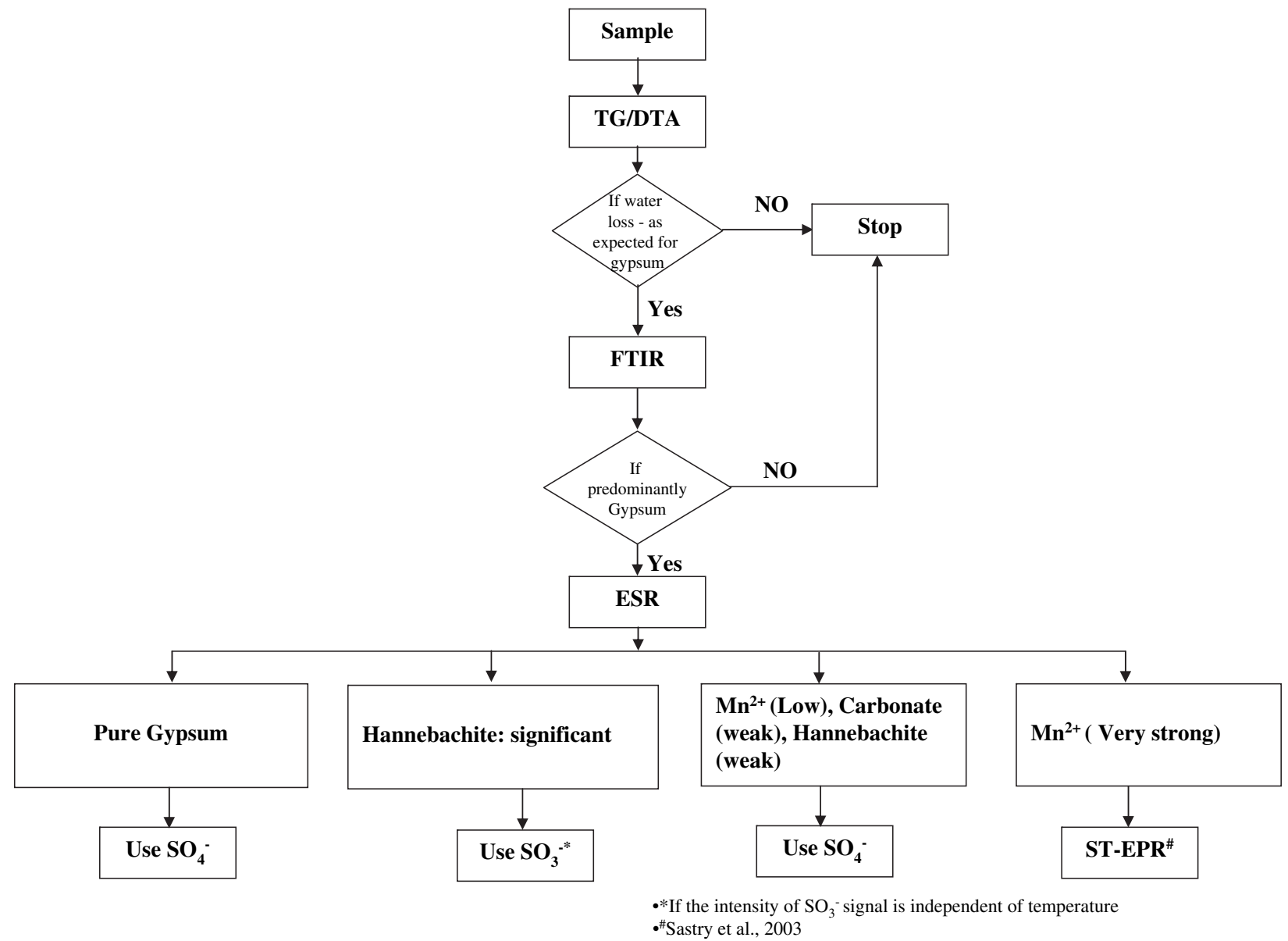

Fig. 10. Protocol for the ESR dating of gypsum.

This is a definitive indicator of a bonding between $\mathrm{SO}_{4}^{-}$with water protons in gypsum and it was confirmed by us using Electron Nuclear Double Resonance (ENDOR) measurements wherein we detected ${ }^{1} \mathrm{H}$ coupled to $\mathrm{SO}_{4}^{-}$which was absent in anhydrite $\mathrm{CaSO}_{4}$. The intensity of $\mathrm{SO}_{4}^{-}$signal increased with dose in all White Sand samples.

The salient aspects of the experimental results pertaining to dating application are,

1. TG/DTA results suggest that both WS and TD samples were gypsum. The loss of water occurred in two temperature steps.

2. The FT-IR and XRD of Thar Desert samples suggested coexistence of sulfite and carbonate along with gypsum. Their relative concentration was sample dependent.

3. The FT-IR of White Sands sample was typical of pure gypsum.

4. Thar Desert samples exhibited an intense $\mathrm{Mn}^{2+}$ signal suggesting a reducing environment during precipitation. This was absent in WS.

5. ESR signals corresponding to $\mathrm{SO}_{4}^{-}$and $\mathrm{SO}_{3}^{-}$provided ages in agreement with control ages for WS TD and AS samples.

6. A light sensitive ESR signal $g=2.001$ was seen in the White Sands samples. This can be examined in detail to date the postdepositional transport of gypsum as sands. The age of gypsum precipitation can be estimated using $\mathrm{SO}_{4}^{-}$. The ages of the precipitation and later transport can possibly be interpreted in terms of contemporary environments.

7. For the White Sands samples, the intensity of $\mathrm{SO}_{3}^{-}$radical, increased on heating. The Thar samples did not show this feature suggesting that for these samples, $\mathrm{SO}_{3}^{-}$belonged to a sulfite phase and hence can be used for dating.
8. $\mathrm{G}_{2}$ signal previously attributed to $\mathrm{CO}_{3}^{-}$, was identified as $\mathrm{SO}_{4}^{-}$, hydrogen bonded to water molecules, and enhances its stability over geological time scales.

9. Samples with multiphase evolution are likely to give erroneous ESR age.

\subsection{Mechanism of gypsum formation}

Observations above suggest that the gypsum formed through different pathways present contrasting behaviors. The White Sands samples gave clear FT-IR and ESR spectra of pure gypsum with radiation chemistry, similar to that of typical alkaline earth sulfates. Thus White Sands gypsum is typical evaporites where the pristine gypsum formed through a simple precipitation of calcium sulfate. This occurred around $5.5 \mathrm{ka}$. The age of aeolian transport using light sensitive signal was $4.5 \mathrm{ka}$. A protocol for dating applications is given in Fig. 10.

The other routes involve anoxic conditions. Sulfur chemistry in lakes relevant to, 1) formation of gypsum, and 2) its transformation to lower oxidation state in the form of mineral such as pyrite, $\mathrm{FeS}_{2}$, or native sulfur, have been extensively investigated (Vairavamurthy et al., 1985; Deprez et al., 1986; Gibson et al., 1991; Warren, 1999; Seal et al., 2000). The role of sulfate reducing bacteria (such as Desulfo- $x$ ) under anaerobic conditions plays a role in bacterial sulfate reduction (BSR) process, and it can operate at temperatures less than $80-110{ }^{\circ} \mathrm{C}$. A typical reaction is,

$$
\mathrm{Ca}^{2+}+2 \mathrm{SO}_{4}^{2-}+2 \mathrm{CH}_{4}+2 \mathrm{H}^{+} \rightarrow 2 \mathrm{H}_{2} \mathrm{~S}+\mathrm{CaCO}_{3}+3 \mathrm{H}_{2} \mathrm{O}+\mathrm{CO}_{2}
$$


Table 6

Probable pathways of gypsum formation and their correlation to the experimental observations.

\begin{tabular}{|c|c|c|}
\hline Favorable conditions & Expected indicators in ESR and FT-IR & Comments \\
\hline $\begin{array}{l}\text { Native sulfur forms } \\
\text { when } \mathrm{H}_{2} \mathrm{~S} \text { accumulates at a near surface } \\
\text { redox interface when } \\
\text { oxygen is present and metaliferrous brines } \\
\text { are absent. It will be devoid of low valent } \\
\text { impurity metal ions like divalent Mn/Fe. }\end{array}$ & $\begin{array}{l}\text { Spectra will be devoid } \\
\text { of signals from metallic impurities like } \mathrm{Mn}^{2+} \mathrm{FT}-\mathrm{IR} \text { will } \\
\text { reflect the completion of gypsum formation. If } \\
\text { incomplete, the spectra due to impurity phases will } \\
\text { show up. Presence of } \mathrm{SO}_{2}^{-} \text {species could be taken as } \\
\text { symptomatic of completed reaction of converting } \\
\text { calcium carbonate in to sulfate. }\end{array}$ & $\begin{array}{l}\text { White sands samples followed this route of } \\
\text { formation. Possibility of gypsum precipitation } \\
\text { in a transition metal free environment exists. }\end{array}$ \\
\hline $\begin{array}{l}\text { Pyrite and low valent transition metal ions get } \\
\text { formed in anoxic water bodies. Change of } \\
\text { these conditions result in weathering of } \\
\text { Pyrite. Gypsum formation through this route } \\
\text { is facilitated by } \mathrm{O}_{2} / \mathrm{H}_{2} \mathrm{O} \text { in the presence of } \\
\text { iron and sulfur oxidizing bacteria such as } \\
\text { Thiobacillus ferrooxidans, and Thiobacillus } \\
\text { thiooxidans. }\end{array}$ & $\begin{array}{l}\text { As sulphite and polythionates exist as reaction } \\
\text { intermediates. The corresponding products can be } \\
\text { observed in case of incomplete reaction, and can be seen } \\
\text { in FT-IR. In ESR an increase in the yield of } \mathrm{SO}_{3}^{-} \text {can be } \\
\text { observed. Accumulation of low valent impurities like } \\
\mathrm{Mn}^{2+} \text { in anoxic conditions, will contaminate the sample } \\
\text { with those ions, and would be observable in ESR. }\end{array}$ & $\begin{array}{l}\text { Thar samples show calcium sulphite in FT-IR, } \\
\text { Presence of intense } \mathrm{Mn}^{2+} \text { lines and increased } \\
\text { yield of } \mathrm{SO}_{3}^{-} \text {radicals are consistent with this } \\
\text { suggestion. Sulfur oxidation and reaction with } \\
\text { calcite appears more likely than pyrite } \\
\text { weathering, as pyrite in general was not found } \\
\text { in playa deposit of Thar Desert. }\end{array}$ \\
\hline
\end{tabular}

In this reaction $\mathrm{CH}_{4}$ is representative of a host of possible hydrocarbons and $\mathrm{SO}_{4}^{2-}$ represents dissolved sulfate. The sulfate reducing bacteria flourish in anoxic waters immediately beneath hyper saline environments and, contribute to the formation of early pyrite framboids. This together with the presence of low valency $\mathrm{Mn}^{2+}$ (taken as an indicator for the formation of gypsum in anoxic waters) leads to the conclusion that metal sulfide/pyrite weathering was responsible for the gypsum formation. Despite these suggestions on possible metal sulfide/pyrite weathering, it is considered less probable due to geological evidences of the absence of pyrite in Thar.

An alternative possibility for the occurrence of calcium sulfite, along with gypsum could be the reaction (Laperche and Bigham, 2002):

$\mathrm{SO}_{2}+\mathrm{CaCO}_{3}+\mathrm{H}_{2} \mathrm{O} \rightarrow \mathrm{CaSO}_{3} \frac{1}{2} \mathrm{H}_{2} \mathrm{O}+\mathrm{CO}_{2}+1 / 2 \mathrm{H}_{2} \mathrm{O}$

The calcium sulfite may be partially or fully oxidized to form calcium sulfate.

$\mathrm{CaSO}_{3} \cdot \frac{1}{2} \mathrm{H}_{2} \mathrm{O}+1 \frac{1}{2} \mathrm{O}_{2}+1.5 \mathrm{H}_{2} \mathrm{O} \rightarrow \mathrm{CaSO}_{4} 2 \mathrm{H}_{2} \mathrm{O}$

It is well known that these reactions are of concern to environmentalists in modern times, and is an easy chemical pathway of reaction of $\mathrm{SO}_{4}$ with calcite. We consider that some of the hannebachite rich samples followed this pathway. The models on the pathways of gypsum formation are summarized in Table 6 .

\section{Conclusions}

The key inferences of the present study are,

1. Radiation-induced paramagnetic centers $\mathrm{SO}_{4}^{-}$and $\mathrm{SO}_{3}^{-}$and a light sensitive $\mathrm{O}_{3}^{-}$center in gypsum are suitable for geochronology of its formation and post-depositional transport.

2. The $\mathrm{SO}_{4}^{-}$and $\mathrm{SO}_{3}^{-}$signals in gypsum have a stability of $>100 \mathrm{ka}$, with hydrogen bonding between sulfate/sulfite oxygen and the water proton contributing to that stability.

3. FT-IR and ESR evidence of hannebachite, calcite and a significant amount of $\mathrm{Mn}^{2+}$ ions in Thar Desert samples suggest less oxidizing formation conditions in Thar Desert playa samples compared to White Sands samples.

Editorial handling by: R. Grun.

\section{References}

Ademic, G., Aitken, M.J., 1998. Dose rate conversion factors: update. Ancient TL 16 $37-49$.

Aitken, M.J., Bowman, S.G.E., 1975. Thermoluminescence dating: assessment of alpha particle contribution. Archaeometry 17, 132-138.

Bowler, J.M., 1998. Willandra Lake revisited: environmental framework for human occupation. Archaeology in Oceania 33, 120-155.

Bowler, J.M., Price, D.M., 1998. Luminescence dates and stratigraphic analysis at Lake Mungo: a review and new perspectives. Archaeology in Oceania 33.

Bowler, J.M., Johnston, H., Olley, J.M., Prescott, J.R., Roberts, R.G., Shawcross, W., Spooner, N., 2003. New ages for human occupation and climatic change at Lake Mungo, Australia. Nature 421, 837-840.

Chivas, A., 2008. Terrestrial evaporites. In: Nash, D., Mcfarlane, S. (Eds.), Geochemical Sediments and Landscapes. Blackwell Publishing, Oxford, UK, pp. 330-364.

Dalvi, A.G.I., Sastry, M.D., Seshagiri, T.K., Joshi, B.D., 1984. Trap level spectroscopy of actinide doped phosphors II $\mathrm{SrSO}_{4}$ : ${ }^{241} \mathrm{Am}$. Journal of Physics C: Solid State Physics 17, 5865-5877.

Danby, R.J., Boas, J.F., Calvert, R.L., Polbrow, J.R., 1982. ESR of thermoluminescent centre in $\mathrm{CaSO}_{4}$ single crystal. Journal of Physics C: Solid State Physics 15, 2483-2493.

Davies, C.P., 2005. Quaternary paleoenvironments and potential for human exploitation of Jordan plateau desert interior. Geoarchaeology 20, 379-400.

Deprez, P.P., Franznann, P.D., Burton, H.R., 1986. Determination of reduced sulfur gases in Antarctic lakes and seawater by gas chromatography after solid adsorbent preconcentration. Journal of Chromatography 362, 9-21.

Gibson, J.A.E., Garrick, R.C., Franzmann, P.D., Deprez, P.P., Burton, H.R., 1991 The production of reduced sulfur gases in saline lakes of the Vestfold Hills, Antarctica. Palaeogeography, Palaeoclimatology, Palaeoecology 84, 131-140.

Grun, R., 1991. Potential and problems of ESR dating. Nuclear Tracks and Radiation Measurements 18, 143-154.

Hentschel, G., Tillmanns, E., Hofmeister, W., 1985. Hannebachite, natural calcium sulpfite hemihydrate, $\mathrm{CaSO}_{3} 1 / 2 \mathrm{H}_{2} \mathrm{O}$. Neues Jahrbuch für Mineralogie - Monatshefte $6,241-250$.

Ikeda, S., Ikeya, M., 1992. Electron spin resonance (ESR) signals in natural and synthetic gypsum: an application of ESR to the age estimation gypsum precipitates from San Andreas Fault. Japanese Journal of Applied Physics 31, L136-L138.

Ikeya, M., 1993. New Applications of Electron Spin Resonance Dating, Dosimetry and Microscopy. World Science, Singapore, New Jersey, Hong Kong.

Ikeya, M., Oka, T., Omura, T., 1997. Evaluation of environment using electron spin resonance; microscpe image of $\mathrm{CaSO}_{4} \cdot 2 \mathrm{H}_{2} \mathrm{O}$ microcrystals in borehole cores at Kenya basin. Japan Review, 193-208.

Kailath, A., Rao, T.K.G., Dhir, R.P., Nambi, K.S.V., Gogte, V., Singhvi, A.K., 2000. Electron spin resonance characterization of calcretes from Thar Desert for dating applications. Radiation Measurements 32, 371-383.

Kasuya, M., Brumby, S., Chappell, J., 1991. ESR signals from natural gypsum single crystals: implications for ESR dating. Nuclear Tracks and Radiation Measurements $18,329-333$.

Laperche, V., Bigham, J.M., 2002. Characterization of flue gas desulfurization by products. Journal of Environmental Quality 31, 978-988.

Magee, J.W., Miller, G.H., Spooner, N.A., Questiaux, D., 2004. Continuous 150 k.y. monsoon record from Lake Eyre, Australia: insolation-forcing implications and unexpected Holocene failure. Geology 32 (10), 885-888.

Marfunin, A.S., 1979. Spectroscopy, Luminescence and Radiation Centers in Minerals. Springer-Verlag, Berlin, Heidelberg, New York, pp. 261.

Mathew, G., Gundu Rao, T.K., Sohoni, P.S., Karanth, R.V., 2004. ESR dating of interfault gypsum from Katrol hill range Kachchh, Gujarat, implications for neotectonism. Current Science 87, 1269-1274. 
Nambi, K.S.V., 1982. ESR and TL studies on marine gypsum. PACT 6, 314-318.

Olley, J.M., Murray, A., Roberts, R., 1996. The effects in disequilibria in the Uranium and Thorium decay chain on burial dose rates in fluvial sediments. Quaternary Science Reviews 15, 751-760.

Pajon, J.M., Hernandez, I., Ortega, F., Macle, J., 2001. Periods of wet climate in Cuba: evaluation of ekarst in Sierra de San Carlos. In: Markgraf, Vera (Ed.), Interhemispheric Climate Linkages. Academic Press, NY, pp. 217-226 (Chapter 13).

Prasad, P.S.R., Chaitanya, V.K., Shivaprasad, K., Narayana Rao, D., 2005. Direct formation of the $\gamma$-CaSO 4 phase process of gypsum: in situ FTIR study. American Mineralogist 90, 672-680.

(Chapter 12) Seal, R.R., Alpers, C.N., Rye, R.O., 2000. In: Alpers, C.N., Ambar, J.L., Nordstrom, D.K. (Eds.), Reviews in Mineralogy and Geochemistry. Sulfate Minerals, vol. 40. Mineralogical Society of America, Geochemical Society, Washington D.C.

Seshagiri, T.K., Dalvi, A.G.I., Sastry, M.D., 1988. Trap level spectroscopy of actinide doped alkaline earth sulphates: I $\mathrm{SrSO}_{4}:{ }^{239} \mathrm{Pu}$ and $\mathrm{CaSO}_{4}:{ }^{239} \mathrm{Pu}$. Journal of Physics C: Solid State Physics 21, 5891-5912.

Singhvi, A.K., Aitken, M.J., 1978. Am-241 for alpha irradiation. Ancient TL 3, 2-9.
Torfstein, A., Gavrieli, I., Katz, A., Stein, M., 2008. Gypsum as a monitor of paleolimno-hydrological condition in Lake Lisan and the Dead Sea. Geochimica et Cosmochimica Acta 72, 2491-2509.

Ulusoy, U., 2004. ESR studies of Antolian gypsum. Spectrochimica Acta Part A: Molecular and Biomolecular Spectroscopy 60, 1359-1365.

Vairavamurthy, A., Andreae, M.O., Iverson, R.L., 1985. Biosynthesis of dimethylsulfide and dimethylpropiothetin by Hymenomonas carterae in relation to sulfur source and salinity variations. Limnology and Oceanography 30 59-70.

Warren, J., 1999. Evaporites - their Evolution and Economics. Chapter 8. In: Evaporite-metal Associations: Lower Temperature and Diagenetic. Blackwell Science.

Yijian, C., Arakel, A.V., Jinfen, L.U., 1989. Investigation of sensitive signals due to gamma irradiations of chemical precipitates: a feasibility study for ESR dating of gypsum, phosphate and calcrete deposits. International Journal of Radiation Applications and Instrumentation. Part A. Applied Radiation and Isotopes 40, 1163-1170. 